\title{
Infectious
}

\section{2-Mercapto-Quinazolinones as Inhibitors of Type II NADH Dehydrogenase and Mycobacterium tuberculosis: Structure-Activity Relationships, Mechanism of Action and Absorption, Distribution, Metabolism, and Excretion Characterization}

Dinakaran Murugesan, ${ }^{\dagger, \alpha}$ Peter C. Ray, ${ }^{\dagger, \alpha}$ Tracy Bayliss, ${ }^{\dagger}$ Gareth A. Prosser, ${ }^{\ddagger}$ Justin R. Harrison, ${ }^{\dagger}$ Kirsteen Green, ${ }^{\dagger}$ Candice Soares de Melo," Tzu-Shean Feng, Leslie J. Street, "Kelly Chibale, ${ }^{\|, \S, \perp_{0}}$ Digby F. Warner, ${ }^{\#,}$ Valerie Mizrahi, ${ }^{\#, \S \odot ~ O l a ~ E p e m o l u, ~}{ }^{\dagger}$ Paul Scullion, ${ }^{\dagger}$ Lucy Ellis, ${ }^{\dagger}$ Jennifer Riley, ${ }^{\dagger}$ Yoko Shishikura, ${ }^{\dagger}$ Liam Ferguson, ${ }^{\dagger}$ Maria Osuna-Cabello, ${ }^{\dagger}$ Kevin D. Read, ${ }^{\dagger}$ Simon R. Green, ${ }^{\dagger}$

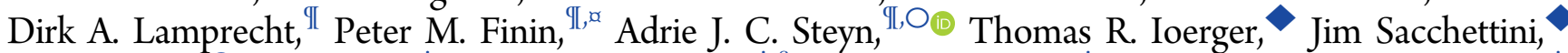
Kyu Y. Rhee, Kriti Arora, ${ }^{\star}$ Clifton E. Barry, III, ${ }^{\ddagger}$, Paul G. Wyatt, ${ }^{* \dagger}{ }^{\dagger}$ and Helena I. M. Boshoff*

${ }^{\dagger}$ Drug Discovery Unit, Division of Biological Chemistry and Drug Discovery, School of Life Sciences, University of Dundee, Sir James Black Centre, Dundee, DD1 5EH, United Kingdom

ॠTuberculosis Research Section, Laboratory of Clinical Immunology and Microbiology, National Institute of Allergy and Infectious Disease, National Institutes of Health, 9000 Rockville Pike, Bethesda, Maryland 20892, United States

${ }^{\S}$ Institute of Infectious Disease and Molecular Medicine, University of Cape Town, Rondebosch, 7701, South Africa

"Drug Discovery and Development Centre (H3D), Department of Chemistry, University of Cape Town, Rondebosch, 7701, South Africa

${ }^{\perp}$ South African Medical Research Council Drug Discovery and Development Research Unit, Department of Chemistry, University of Cape Town, Rondebosch, 7701, South Africa

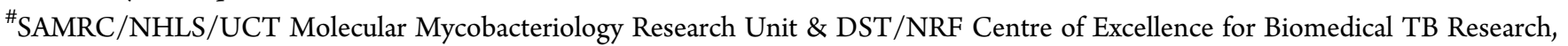
Department of Pathology, Faculty of Health Sciences, University of Cape Town, Rondebosch, 7701, South Africa

${ }^{I}$ Africa Health Research Institute (AHRI), K-RITH Tower Building Level 3, 719 Umbilo Road, Durban, 4001, South Africa

ODepartment of Microbiology, University of Alabama at Birmingham, 1720 Second Avenue South, Birmingham, Alabama 35294-2170, United States

Department of Computer Science and Engineering, Texas A\&M University, College Station, Texas 77843, United States

•Division of Infectious Diseases, Weill Department of Medicine, Weill Cornell Medical College, New York, New York 10065, United States

Supporting Information

\begin{tabular}{|c|c|c|c|c|}
\hline & 1 & 7 & 24 & 11 \\
\hline $\operatorname{MIC}(\mu \mathrm{M})$ & 0.3 & 0.4 & 1.5 & 0.8 \\
\hline cLogP & 2.3 & 2.3 & 1.8 & 2.6 \\
\hline Kin. Solubility ( $\mu \mathrm{M})$ & 83 & 105 & $>250$ & $>250$ \\
\hline $\begin{array}{c}\text { Microsomal Cli } \\
\text { Mouse }(\mathrm{mL} / \mathrm{min} / \mathrm{g})\end{array}$ & 2.3 & 1.4 & 1.2 & 4.7 \\
\hline
\end{tabular}

ABSTRACT: Mycobacterium tuberculosis ( $M T$ b) possesses two nonproton pumping type II NADH dehydrogenase (NDH-2) enzymes which are predicted to be jointly essential for respiratory metabolism. Furthermore, the structure of a closely related bacterial $\mathrm{NDH}-2$ has been reported recently, allowing for the structure-based design of small-molecule inhibitors. Herein, we disclose $M T b$ continued... 
whole-cell structure-activity relationships (SARs) for a series of 2-mercapto-quinazolinones which target the $n d h$ encoded NDH-2 with nanomolar potencies. The compounds were inactivated by glutathione-dependent adduct formation as well as quinazolinone oxidation in microsomes. Pharmacokinetic studies demonstrated modest bioavailability and compound exposures. Resistance to the compounds in $M T b$ was conferred by promoter mutations in the alternative nonessential NDH-2 encoded by $n d h A$ in $M T b$. Bioenergetic analyses revealed a decrease in oxygen consumption rates in response to inhibitor in cells in which membrane potential was uncoupled from ATP production, while inverted membrane vesicles showed mercapto-quinazolinone-dependent inhibition of ATP production when NADH was the electron donor to the respiratory chain. Enzyme kinetic studies further demonstrated noncompetitive inhibition, suggesting binding of this scaffold to an allosteric site. In summary, while the initial MTb SAR showed limited improvement in potency, these results, combined with structural information on the bacterial protein, will aid in the future discovery of new and improved NDH-2 inhibitors.

KEYWORDS: Mycobacterium tuberculosis, mercapto-quinazolinones, structure-activity relationship, type II NADH dehydrogenase, small molecule NDH-2 inhibitors, respiration

$\mathrm{T}$ uberculosis (TB) is a major global health problem, resulting in significant morbidity each year. Although mortality has fallen dramatically since 1990, TB now ranks alongside HIV as a leading cause of death worldwide. While HIV-related deaths have been declining largely as a result of improved access to, and availability of, better HIV treatments, this has not been the case for $\mathrm{TB},{ }^{1}$ the treatment of which requires 6 months of chemotherapy with a combination of four agents (isoniazid, rifampicin, pyrazinamide, and ethambutol) to achieve durable cure of drugsensitive TB. ${ }^{2}$ The large number of TB patients, coupled with the chemotherapeutic burden, often leads to poor patient adherence and suboptimal treatment outcomes in the developing world, as well as the emergence of multidrug resistant TB (MDR-TB, defined as resistance to isoniazid (INH) and rifampicin (RIF)) and extensively drug-resistant tuberculosis (XDR-TB, defined as MDR-TB plus resistance to any fluoroquinolone and one of three second-line injectable drugs, capreomycin, kanamycin (Kan), and amikacin). To address this global TB health problem, an improved treatment regimen is needed which will reduce treatment duration and prevent relapse and the development of TB drug resistance. ${ }^{3-8}$ However, achieving this goal will require discovery of multiple novel and mechanistically distinct antimycobacterial agents possessing reduced liabilities for investigation of new drug regimens that might shorten the duration of treatment and simplify management of the disease by improving adherence and reducing costs. ${ }^{9-12}$

Identification of novel drug targets that will lead to treatment shortening is challenging. Targets of drugs currently in use or phase 3 clinical evaluation for TB chemotherapy include cell wall biosynthesis, translation, transcription, folate synthesis, ATP generation, and maintenance of DNA topology as broad categories, although the nitroimidazoles delaminid and pretomanid generate reactive nitrogen intermediates that inhibit several essential processes. ${ }^{13}$ Mechanistically novel drugs would conceptually target distinct processes from the above, and to date, successes in the field have all emerged from target identification of hits discovered in Mycobacterium tuberculosis (MTb) whole cell screens. ${ }^{13}$

In this work, we describe the identification of a 2-mercaptoquinazoline scaffold identified from a $M T b$ whole cell screen, which had been previously reported to inhibit the mycobacterial type II $\mathrm{NADH}$ dehydrogenase, ${ }^{14}$ providing further evidence for its inhibition of the $M T b$ type II NADH dehydrogenase (NDH-2). $M T b$ encodes two NDH-2 genes of which the one encoded by $n d h$ plays a critical role for growth both in vitro and in vivo. ${ }^{15-17}$ $\mathrm{NDH}-2$ catalyzes the transfer of electrons from $\mathrm{NADH}$ into the mycobacterial respiratory pathway and has been proposed to be targeted by a number of early stage inhibitors. ${ }^{16,18-20}$ In contrast, the proton pumping type I NADH dehydrogenase can be deleted without apparent effects on growth both in vitro or in vivo. ${ }^{15-17}$ As the current series was considered to have a promising druglike profile (Table 1), a focused optimization program was initiated.

\section{RESULTS AND DISCUSSION}

Screening of a commercial diversity library, details of which will be published elsewhere, afforded a 2-mercapto-quinazolinone

Table 1. Profiling of Confirmed Hits 1, 2, and 3

\begin{tabular}{|c|c|c|c|}
\hline Confirmed hits & 1 & $2^{110}$ & 3 \\
\hline GAST MIC ( $\mu \mathrm{M})$ & 0.3 & 5.9 & 43 \\
\hline 7H9-ADC MIC $(\mu \mathrm{M})$ & 0.6 & 4.5 & $>50$ \\
\hline GAST LLE & 4.2 & 3.5 & 1.7 \\
\hline Cyd KO reporter & Not likely QcrB inhibitor & Not likely QcrB inhibitor & - \\
\hline pini-LUC reporter & Not likely cell wall inhibitor & Not likely cell wall inhibitor & - \\
\hline HepG2 IC ${ }_{50}(\mu \mathrm{M})$ & $>50$ & - & - \\
\hline CHI-LogD & 1.8 & 1.5 & - \\
\hline $\begin{array}{l}\text { Microsomal Cli } \\
(\mathrm{mL} / \mathrm{min} / \mathrm{g})\end{array}$ & $\begin{array}{c}\text { Mouse } 2.3 \\
\text { Human }<0.5\end{array}$ & Mouse 1.6 & - \\
\hline $\mathrm{MW}^{\mathrm{a}}$ & 317 & 325 & 337 \\
\hline $\operatorname{clog} P^{a} / \operatorname{clog} D^{a}$ & $2.3 / 2.3$ & $1.7 / 1.7$ & $2.7 / 2.7$ \\
\hline TPSA $^{\mathrm{a}}$ & 75 & 75 & 75 \\
\hline $\begin{array}{l}\text { Kin. solubility } \\
(\mu \mathrm{M})^{\mathrm{b}}\end{array}$ & 83 & 109 & - \\
\hline PFI & 4.7 & 4.3 & 4.7 \\
\hline
\end{tabular}

${ }^{a}$ Calculated using StarDrop (http://www.optibrium.com). ${ }^{b}$ Kinetic aqueous solubility was measured using laser nephelometry of compounds in $2.5 \%$ DMSO. 
Scheme 1. General Synthetic Route for Synthesis of Quinazolinone Amides ${ }^{a}$

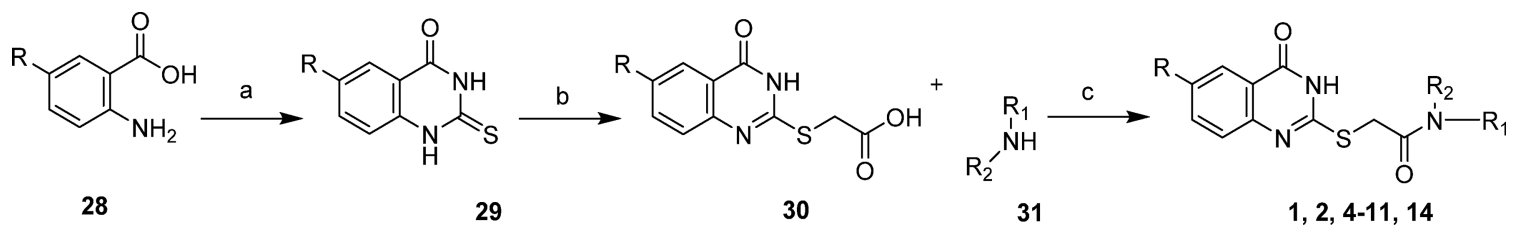

${ }^{a}$ Reagents and conditions: General synthetic approach to quinazolinones 1, 2, 4-11, and 14: (a) neat thiourea at $180{ }^{\circ} \mathrm{C}, 3 \mathrm{~h}$; (b) 2-bromoacetic acid, triethylamine, DMF, $80^{\circ} \mathrm{C}, 12 \mathrm{~h}$; (c) primary and/or secondary amine 31, EDC.HCl, HOAT, N,N-diisopropylethylamine, DMF/ACN (1:1), room temperature, $12 \mathrm{~h}$ or primary and/or secondary amine 31, HATU, $N, N$-diisopropylethylamine, DCM, room temperature, $12 \mathrm{~h}$.

cluster of hits (1, 2, and 3), with compounds 1 and 2 showing potent $M T b$ whole-cell minimum inhibitory concentration (MIC) in two distinct growth media. The compounds were assessed in a series of early stage biology profiling assays to understand better the mechanism of action (MoA). These included screening the compounds against a cyd knockout strain which is known to be hyper-susceptible to inhibitors of the cytochrome $b c_{1}$ complex, ${ }^{21}$ which suggested that the series was unlikely to target QcrB. Profiling also investigated the extent of upregulation of the promoter of the iniBAC gene cluster, known to be induced by inhibitors of cell wall biosynthesis, such as isoniazid, ethionamide, SQ109, and ethambutol, ${ }^{22,23}$ which suggested $\mathbf{1}$ and $\mathbf{2}$ did not have an effect on cell wall biosynthesis. These biology profiling data were considered promising, especially in conjunction with a recent report ${ }^{14}$ in which mutations in $M T b$ mutants spontaneously resistant to compound 1 mapped to $n d h A$, the gene encoding the nonessential type-II NADH dehydrogenase that is involved in $\mathrm{NADH}$ reoxidation in the mycobacterial oxidative phosphorylation pathway. ${ }^{14}$ There are two closely related nonproton pumping type II $\mathrm{NADH}$ dehydrogenases in the $M T b$ genome, of which only one (encoded by $n d h, \mathrm{Rv} 1854 \mathrm{c}$ ) is essential. ${ }^{24-27}$ Ioerger et al. ${ }^{14}$ identified promoter mutations in $n d h A$ which resulted in $>40$-fold upregulation of gene expression, likely compensating for compound 1 inhibiting the essential NDH-2 homologue.

Compound $\mathbf{1}$ had a promising MTb MIC-derived ligandlipophilicity efficiency (LLE) drug-likeness profile, suggestive of a quality starting point for medicinal chemistry optimization. ${ }^{28,29}$ Compound $\mathbf{1}$ also showed no noticeable cytotoxicity in a mammalian cell line (HepG2). Compounds $\mathbf{1}$ and $\mathbf{2}$ also had moderate kinetic solubility and reasonable mouse hepatic microsomal stability, with 1 having excellent human microsomal stability (Table 1). Herein, we report on the development of the structure-activity relationship (SAR) for 1, as well as extended absorption, distribution, metabolism, and excretion (ADME) characterization of key compounds.

Synthetic Chemistry. Quinazolinone amides reported herein were synthesized utilizing known procedures, which are detailed in Scheme 1. Commercially available anthranilic acids (28) were cyclized with thiourea, and the resulting 2-mercapto quinazoline4-diones (29) or commercially available 2-mercapto-4(3H)quinazolinone was reacted with 2-bromo acetic acid to form the 2-((4-oxo-3,4-dihydroquinazolin-2-yl)thio)acetic acids (30). Primary and secondary amines (31) were coupled using standard coupling reagents to afford compounds 1, 2, 4-11, and 14 .

MTb Whole-Cell SAR. The initial medicinal chemistry plan focused on developing the SAR with the aim of better understanding the pharmacophore. Initial efforts were guided by mouse microsomal metabolite identification (met-ID) studies on 1, which revealed significant oxidation of the cyclohexyl and quinazolin$4(3 \mathrm{H})$-one rings as well as cleavage of the amide bond (Figure S1). To understand the scope, cycloalkyls 4,5 , and 6 were prepared
(Table 2). The large bulky lipophilic cyclohexyl $\mathbf{1}$ and cycloheptyl 4 were both equally favored, with good whole-cell

Table 2. Evaluation R1 (Cyclohexyl) SAR<smiles>[R]NC(=O)CSc1nc2ccccc2c(=O)[nH]1</smiles>

\begin{tabular}{|c|c|c|c|c|c|c|}
\hline ID & $R_{1}$ & & $\begin{array}{l}\text { Rv MIC } \\
\mu \mathrm{M})\end{array}$ & cLogP & $\begin{array}{c}\text { Mouse } \\
\mathrm{Cli}^{b}\end{array}$ & Solubility \\
\hline & & GAST & & & & \\
\hline 4 & & 0.3 & 0.6 & 2.9 & 6.4 & 39 \\
\hline 5 & & 1.0 & 1.8 & 1.6 & 2.5 & 101 \\
\hline 6 & & 1.6 & 1.6 & 1.2 & 1.8 & 219 \\
\hline 7 & & 0.4 & 0.4 & 2.3 & 1.4 & 105 \\
\hline 8 & & 9.4 & 12.5 & 2.3 & 2.3 & 219 \\
\hline 9 & & 4.7 & 4.7 & 2.3 & 2.9 & 187 \\
\hline 10 & & 0.2 & 0.3 & 2.6 & 5.9 & - \\
\hline 11 & & 0.8 & 1.1 & 2.6 & 4.7 & 250 \\
\hline
\end{tabular}

${ }^{a}$ Minimum inhibitory concentration (MIC) is the minimum concentration required to inhibit $>99 \%$ growth of M. tuberculosis in liquid culture. Isoniazid was included as an internal control reference compound (MIC of $0.2 \pm 0.1 \mu \mathrm{M}$ ). ${ }^{b}$ Intrinsic clearance (Cli) using CD1 mouse liver microsomes. ${ }^{c}$ Kinetic aqueous solubility was measured using laser nephelometry of compounds in $2.5 \%$ DMSO.

MIC potency. In contrast, the smaller ring-contracted cyclopentyl 5 and cyclobutyl 6 were slightly less potent (Table 2), and the cyclopropyl and ring deletion NHMe analogues (data not shown) resulted in a complete loss of whole-cell activity, suggesting that a bulky hydrophobic group was required to obtain good whole-cell potency. As mouse met-ID of 1 showed significant oxidation of the cyclohexyl group, the 2-, 3-, and 4-hydroxylated cyclohexyl derivatives were prepared with the aim of improving solubility as well as microsomal stability. Improvements in both kinetic solubility and mouse microsomal stability were indeed achieved, but no whole-cell activity was observed (data not shown). An additional focused set of polar saturated 4-, 5-, and 6-membered oxygen-containing saturated heterocycles was prepared; however, while having good kinetic solubility and mouse microsomal stability, they too lost all whole-cell activity (data not shown). 


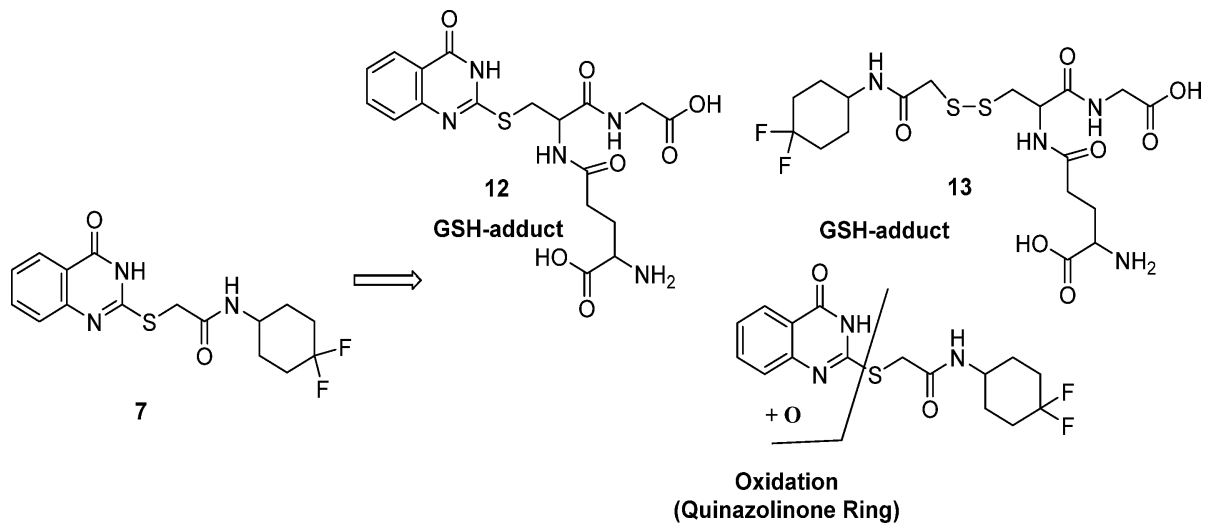

Figure 1. Metabolite identification of 7 in a GSH trapping experiment.

There were also attempts to improve solubility with differentially functionalized 4-substituted piperidines ( $\mathrm{NAc}, \mathrm{NSO}_{2} \mathrm{Me}, \mathrm{NMe}$, and $\mathrm{NBn}$ ), but once again, there was a loss of whole-cell activity (data not shown). As the cyclohexyl group within 1 did not appear to tolerate polar solubilizing groups, we turned our focus to introducing fluorine in an attempt to improve microsomal stability. ${ }^{30,31}$ We were encouraged to find that the 4,4-difluorocyclohexan 7 retained good whole-cell potency and also had slightly improved mouse microsomal stability versus 1 . In comparison to 1 , mouse microsomal met-ID on 7 showed a small amount of amide bond cleavage as well as oxidation of the quinazolin$4(3 \mathrm{H})$-one ring (Figure S2). The 2,2- and 3,3-difluorocyclohexan compounds $\mathbf{8}$ and $\mathbf{9}$ had moderate to poor whole-cell potency. Met-ID for both 1 and 7 revealed cleavage of the amide bond, so attempts to hinder the amide through formation of the 1-methyl-, 1-methanol-, and 1-cyano-substituted cyclohexane were explored, all of which resulted in a complete loss of MIC potency as well as increased mouse microsomal instability (data not shown). Addition of a methylene bridge in $\mathbf{1}$ and 7 to afford $\mathbf{1 0}$ and $\mathbf{1 1}$ improved MIC potency, further emphasizing the requirement for bulky lipophilic groups.

There were concerns over the S-linker, based on previous experience from whole-cell screening where confirmed hits with similar S-linker compounds were found to react with glutathione (GSH) both with and without microsomal activation. GSH trapping on 7, with and without human liver microsomes (Figure S3), showed GSH adducts 12 and 13, without microsomal activation. It is presumed that GSH results in cleavage of the sulfurquinazolinone 7 linker, to afford 12, with GSH coupling to the displaced S-linker to afford 13. Human microsomal oxidation of the quinazolinone ring of 7 was also observed (see Figure 1).

While the level of GSH adduct formation for 7 was relatively low and no HepG2 cytotoxicity was observed, this was considered a liability of the series as the reactivity did not require microsomal activation and the ability to predict and quantify the risk of idiosyncratic adverse drug reactions is limited. ${ }^{32,33}$ We attempted to reduce this liability by modifying the linker. $\mathrm{N}$-Methylation of the amide and/or the methylene linker to afford 14, 15, and 16, was not tolerated. The $\mathrm{NH}$-, $\mathrm{O}$-, and $\mathrm{CH}_{2}$-linkers were readily prepared to afford 17,18 , and 19 . However, all resulted in a loss of MIC potency (see Table 3). Oxidation of $\mathrm{S}$-atom in compound $\mathbf{1}$ was attempted using a variety of conditions and oxidation reagents (for example, 3-chlorobenzoic acid, potassium permanganate, and Oxone). However, all attempts failed to deliver the desired sulfone, possibly as a result of increased reactivity.

Changes to the quinazolinone ring were then explored, starting with $\mathrm{N}$-methylation to afford 20, which was not tolerated. Removal of the carbonyl, by synthesis of quinazoline 21 and quinazolin-4-amine 22, was also not tolerated. Saturation of the quinazolinone core phenyl afforded 23, which retained good MIC potency and also resulted in improved solubility, albeit microsomal stability was poor. The related 5-membered saturated analogue 24 showed similar MIC potency but with improved microsomal stability as well as solubility. However, the dimethyl analogue $\mathbf{2 5}$ was less well tolerated, suggesting that a bulky hydrophobic ring was preferred. The above SAR suggested that the pyrimidinone core was a key part of the pharmacophore. As human-metID showed oxidation of the quinazolinone ring of 7 , we synthesized the presumably more stable fluorine analogue 26 which, while not as potent as 7 , retained good MIC potency. However, the solubility was poor, and the mouse microsomal stability was moderate. In an attempt to improve solubility as well as microsomal stability, the pyridopyrimidinone $\mathbf{2 7}$ was prepared; while solubility and microsomal stability were improved, the compound had moderate to weak MIC potency. A summary of the overall whole-cell SAR for $\mathbf{1}$, as well as the effects on both kinetic solubility and microsomal stability, is shown in Figure 2 and in Tables 2-4.

Pharmacokinetic studies were initiated in order to assess the potential for in vivo efficacy studies of the 2-mercaptoquinazolinones. Compound 1, when dosed as the free base, had reasonable bioavailability, consistent with its moderate Cli and solubility, and good permeability (Table 5). Compound 7 showed a similar bioavailability and exposure profile to $\mathbf{1}$ (Table 5).

As compound 7 had comparable MIC potency, mouse microsomal stability, and pharmacokinetic profile to 1 , a dose linearity study was conducted to evaluate if exposures above the MIC could be achieved. However, no dose linearity was observed between the 30 and $100 \mathrm{mg} / \mathrm{kg}$ doses, determined by the area under the curve (AUC) comparison (Figure S4). This may be a consequence of solubility limited absorption at the highest dose. Compound 11 demonstrated better kinetic solubility and comparable MIC to compounds 1 and 7, yet despite an improved $C_{\max }$ and $T_{\max }$ compared to compound 1 , likely driven by its improved kinetic solubility, it had a lower exposure (AUC) over time (Figure S5 and Table 5), likely a consequence of it is higher clearance (mouse Cli $4.7 \mathrm{~mL} / \mathrm{min} / \mathrm{g}$ versus 2.3 or 1.4 for compounds 1 and 7 , respectively). The modest compound exposures upon oral dosing, combined with the lack of ex vivo intramacrophage efficacy (vide infra), suggested that efficacy studies of these compounds in infected mice were unlikely to validate the target/drug candidate pair in an animal model where the disease is macrophage-based. As such, an efficacy experiment was not performed. 
Table 3. Evaluation of S-Linker SAR

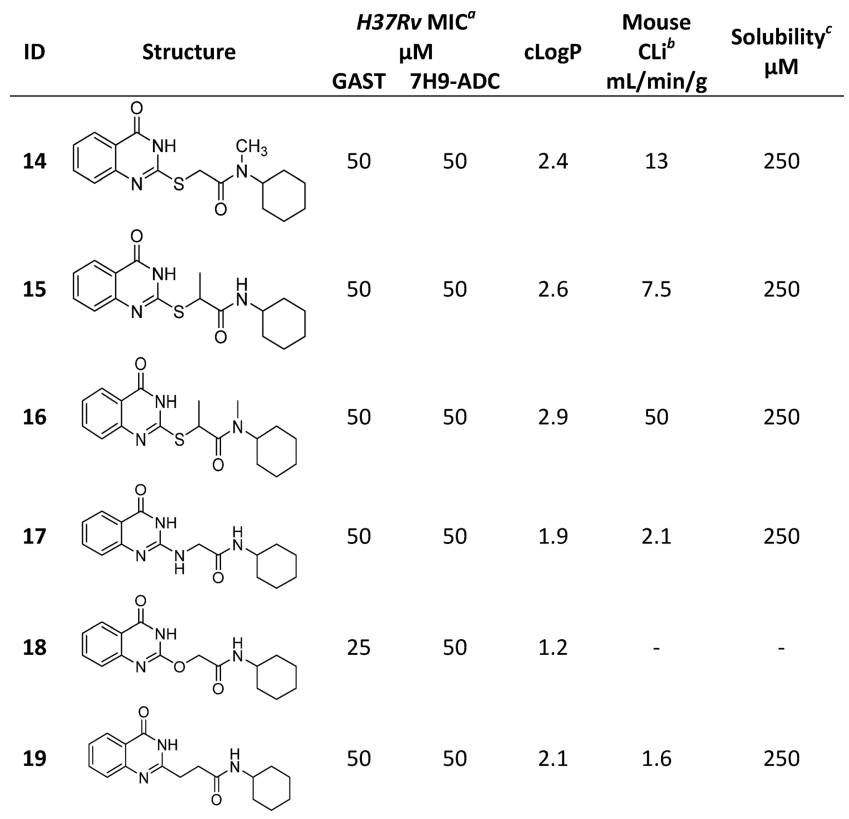

${ }^{a}$ Minimum inhibitory concentration (MIC) is the minimum concentration required to inhibit $>99 \%$ growth of $M$. tuberculosis in liquid culture. Isoniazid was included as an internal control reference compound (MIC of $0.2 \pm 0.1 \mu \mathrm{M}$ ). ${ }^{b}$ Intrinsic clearance (Cli) using CD1 mouse liver microsomes. ${ }^{c}$ Kinetic aqueous solubility was measured using laser nephelometry of compounds in 2.5\% DMSO.

Biological Characterization of the Mercapto-Quinazolinones. Previous work on a mercapto-quinazolinone had suggested that compound 1 might target $\mathrm{NDH}-2$ as evidenced by promoter mutations in the nonessential $n d h A$ gene encoding an orthologue of the type II NADH dehydrogenase. ${ }^{14}$ We similarly identified promoter mutations for $n d h A$ but were not able to identify polymorphisms in the apparently essential $n d h$ (Rv1854c) (Table S1) suggesting either that mutations were deleterious for enzyme function or that single amino acid mutations alone might not sufficiently decrease affinity of this putative inhibitor. The upregulation of $n d h A$ could serve to compensate for loss of NDH-2 function or could serve to bind excess inhibitor in the cell. It is intriguing that $n d h$ promoter mutations were not identified possibly because this gene is not readily upregulated by single nucleotide substitutions in its promoter. We also identified mutations in Rv0678 (Table S1) encoding a transcriptional repressor that has previously been demonstrated to control expression of the MmpS5-MmpL5 transporter and has been implicated in resistance to bedaquiline and clofazimine. ${ }^{34}$ In accordance with
Table 4. Evaluation of Quinazolinone Core

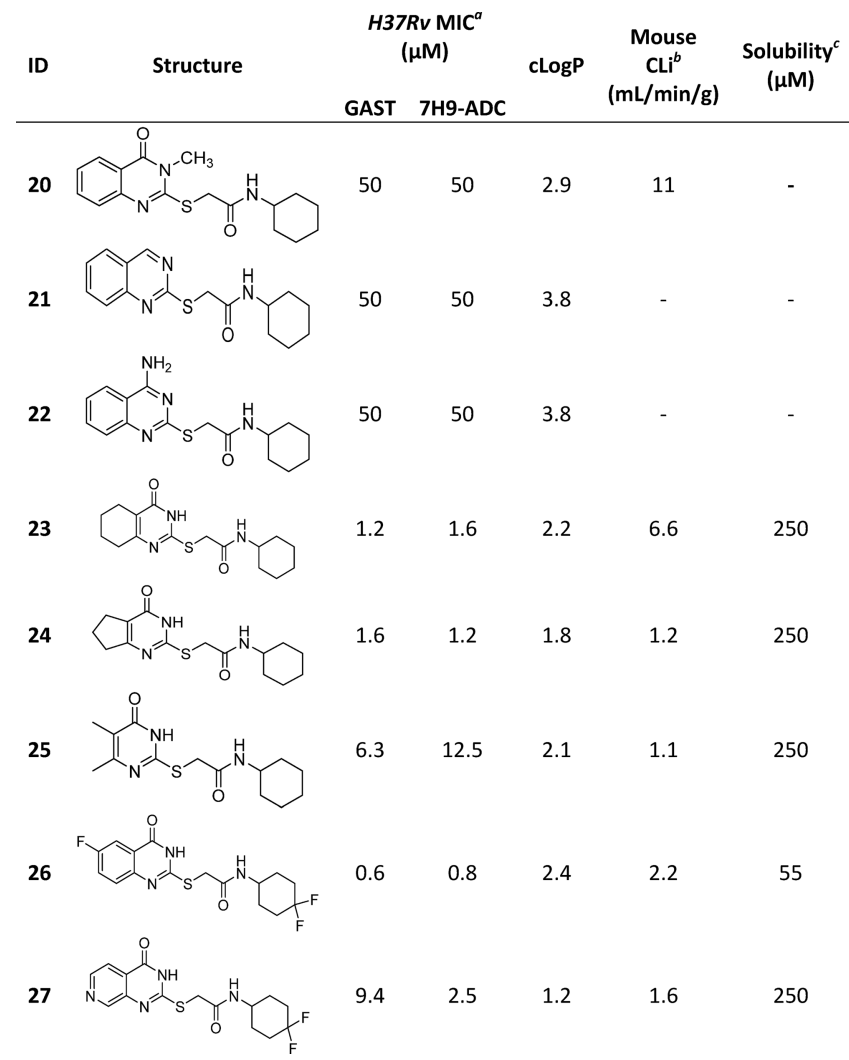

${ }^{a}$ Minimum inhibitory concentration (MIC) is the minimum concentration required to inhibit $>99 \%$ growth of $M$. tuberculosis in liquid culture. Isoniazid was included as an internal control reference compound (MIC of $0.2 \pm 0.1 \mu \mathrm{M}$ ). ${ }^{b}$ Intrinsic clearance (Cli) using CD1 mouse liver microsomes. ${ }^{c}$ Kinetic aqueous solubility was measured using laser nephelometry of compounds in $2.5 \%$ DMSO.

the predicted essential role of NDH-2 as complex I in oxidative phosphorylation, ${ }^{16}$ treatment of $M T b$ with compound 1 resulted in depletion of cellular ATP levels, a phenomenon also observed with bedaquiline (TM207), an inhibitor of the ATP synthase, as well as EU306, an inhibitor of the cytochrome $b c_{1}$ complex $^{35}$ but not with inhibitors of macromolecular biosynthesis including INH (cell wall), Rif (RNA polymerase), and Kan (protein synthesis) (Figure 3).

We predicted that inhibition of NDH-2 would result in a more severe phenotype on a mutant lacking the second copy of the type II NADH dehydrogenase. Indeed, while treatment of wild-type $M T b \mathrm{H} 37 \mathrm{Rv}$ at MIC concentrations could not fully suppress growth of cells over 7 days of treatment, similar

Linker modifications generally not tolerated

Microsomal metabolite ID shows amide cleavage

Glutathione adduct / displacement of S-linker a concern

$\mathrm{S}$ to $\mathrm{O}, \mathrm{NH}$ and $\mathrm{CH}_{2}$ not tolerated

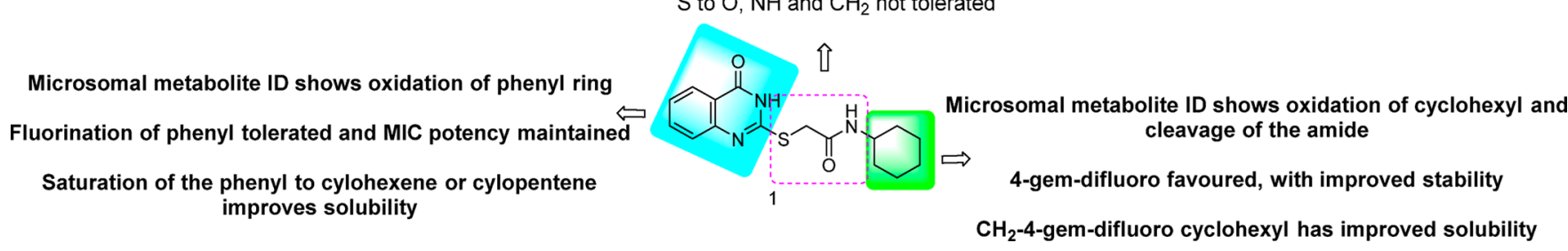

Figure 2. Overview of structure-activity and property relationships of the mercapto-quinazolinones. 
Table 5. Pharmacokinetic Profiling of Compounds 1, 7, and 11

\begin{tabular}{|c|c|c|c|}
\hline & 1 & 7 & 11 \\
\hline GAST MIC $(\mu \mathrm{M})$ & $0.3(95 \mathrm{ng} / \mathrm{mL})$ & $0.4(141 \mathrm{ng} / \mathrm{mL})$ & $0.8(294 \mathrm{ng} / \mathrm{mL})$ \\
\hline 7H9-ADC MIC $(\mu \mathrm{M})$ & $0.6(190 \mathrm{ng} / \mathrm{mL})$ & $0.4(141 \mathrm{ng} / \mathrm{mL})$ & $0.8(294 \mathrm{ng} / \mathrm{mL})$ \\
\hline HepG2 $\mathrm{IC}_{50}(\mu \mathrm{M})$ & $>50$ & $>50$ & $>50$ \\
\hline measured CHI-LogD & 1.8 & 1.5 & 1.6 \\
\hline \multirow[t]{2}{*}{ microsomal clearance $(\mathrm{mL} / \mathrm{min} / \mathrm{g})$} & mouse 2.3 & mouse 1.4 & mouse 4.8 \\
\hline & human $<0.5$ & & \\
\hline $\mathrm{MW}^{a}$ & 317 & 353 & 367 \\
\hline $\operatorname{cLog} \mathrm{P}^{a} / \operatorname{cLog} \mathrm{D}^{a}$ & $2.3 / 2.3$ & $2.3 / 2.3$ & $2.7 / 2.7$ \\
\hline TPSA $^{a}$ & 75 & 75 & 75 \\
\hline PAMPA $(\mathrm{nm} / \mathrm{s})$ & 83 & 64 & 65 \\
\hline kinetic solubility $(\mu \mathrm{M})^{b}$ & 83 (free base) & 111 ( $\mathrm{HCl}$ salt $)$ & $>250$ \\
\hline C57 mouse PK at 3 iv and 10 po $(\mathrm{mg} / \mathrm{kg})$ & free base & $\mathrm{HCl}$ salt & free base \\
\hline$C_{\max }(\mathrm{ng} / \mathrm{mL})$ & 748 & 399 & 1112 \\
\hline$T_{1 / 2}(\mathrm{~h})$ & 1.5 & 1.3 & \\
\hline $\mathrm{AUC}_{0-8 \mathrm{~h}}(\mathrm{ng} \cdot \mathrm{min} / \mathrm{mL})$ & 156800 & 67085 & 128309 \\
\hline $\mathrm{Cl}_{\mathrm{b}}(\mathrm{mL} / \mathrm{min} / \mathrm{kg})$ & 23 & 39 & \\
\hline $\mathrm{Vd}_{\mathrm{ss}}(\mathrm{L} / \mathrm{kg})$ & 0.8 & 1 & \\
\hline$\% \mathrm{~F}$ & 46 & 29 & \\
\hline PPB (\% unbound) & 14 & 13 & 21 \\
\hline
\end{tabular}

${ }^{a}$ Calculated using StarDrop (http://www.optibrium.com). ${ }^{b}$ Kinetic aqueous solubility was measured using laser nephelometry of compounds in $2.5 \%$ DMSO.

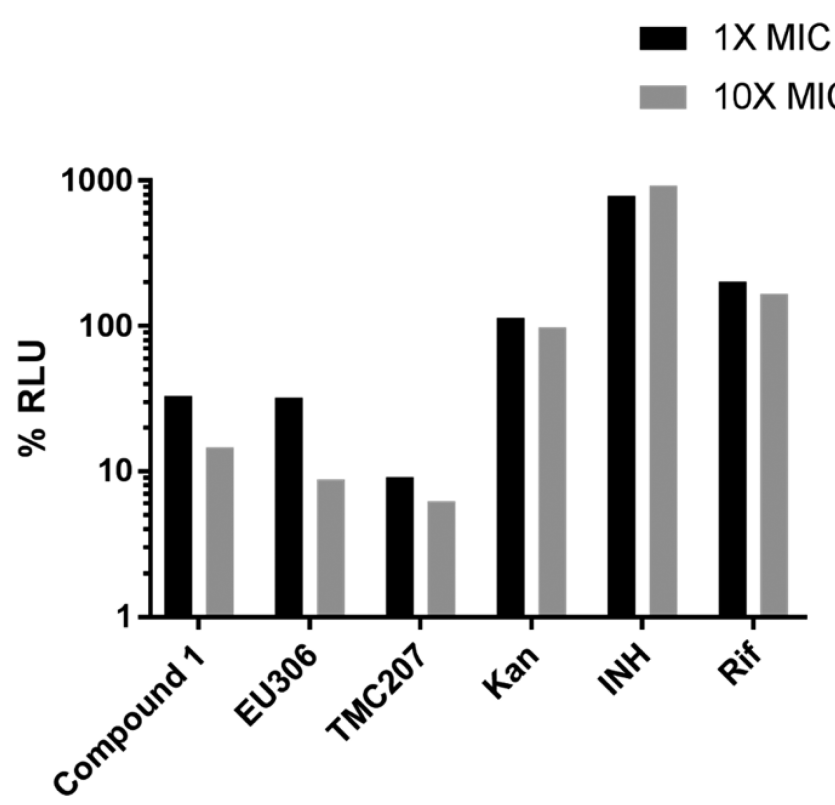

Figure 3. Mercapto-quinazolinones deplete cellular ATP levels in $M T b$. ATP was measured using the BacTiter Glo assay after $24 \mathrm{~h}$ of drug exposure and expressed as a fraction of the drug-free vehicle control levels.

concentrations of compound resulted in an almost 2-log kill of a $\Delta n d h A$ mutant (Figure 4). Despite the higher vulnerability of the $n d h A$ mutant to killing by compound 1, the MIC to this strain, as well as a $n u o G$ deletion mutant lacking a functional type I NADH dehydrogenase, was indistinguishable from WT cells (results not shown). Inhibition of anaerobic nonreplicating cells with compound 1 did not affect viability (Figure S6) which contrasts with the anaerobic cidal activity of other NDH-2 inhibitors including the phenothiazines ${ }^{16}$ and a recently described quinolone scaffold, ${ }^{19}$ possibly due to differences in compound access to the target under anaerobic conditions or to growth-dependent differences in compound modification by $M T b$. In addition, this compound lacked activity against $M T b$ growing in infected macrophages (Figure S7) possibly due

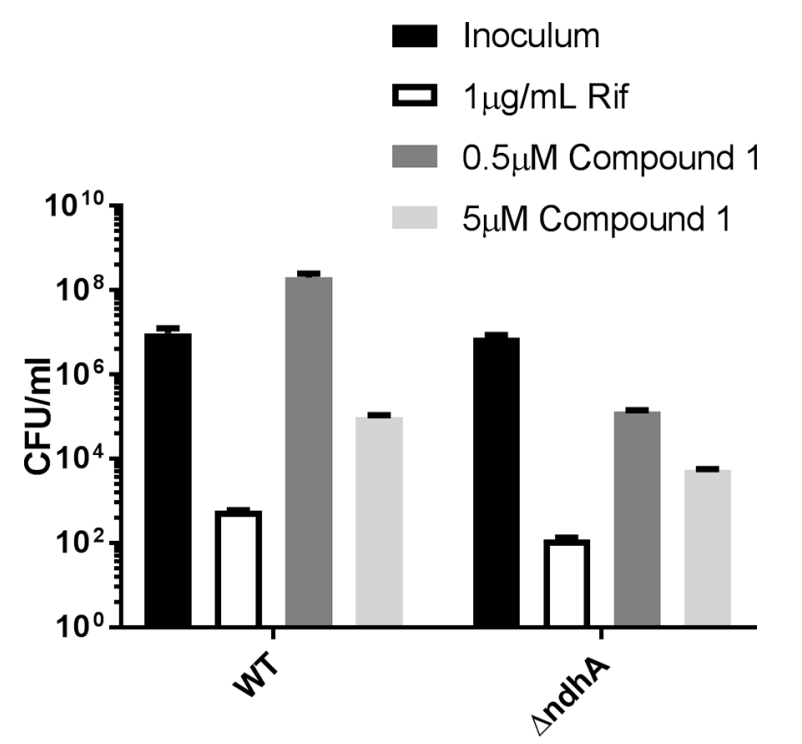

Figure 4. $M t b$ lacking the alternative type II NADH dehydrogenase encoded by $n d h A$ was more susceptible to compound 1 . Colonyforming units (CFU) after 7 days of treatment as compared to CFU at start of drug treatment (inoculum). Unpaired $t$ test comparison between WT and $\Delta n d h A$ at $0.5 \mu \mathrm{M}$ compound 1: two-tailed $P$-value $=0.0023$.

GSH-catalyzed compound inactivation or inability to access the mycobacterial phagosome.

The effect of the mercapto-quinazolinones on $M T b$ bioenergetics in whole cells was further demonstrated by analysis of the mycobacterial oxygen consumption rate (OCR) (Figure 5). Addition of compounds 1 and 7 had a minimal effect on basal $M T b$ OCR levels over $\sim 45 \mathrm{~min}$. The same results were obtained in the presence of glucose or palmitate as carbon sources (Figure 5A,B). Uncoupling of $M T b$ oxidative phosphorylation (OXPHOS) with carbonyl cyanide $m$-chlorophenyl hydrazone (CCCP) significantly diminished maximal respiration in the presence of the two inhibitors compared to the untreated control. These findings suggest an energy generation pathway common to both fatty acid and glucose oxidation as the target of the compounds. Previous 
A

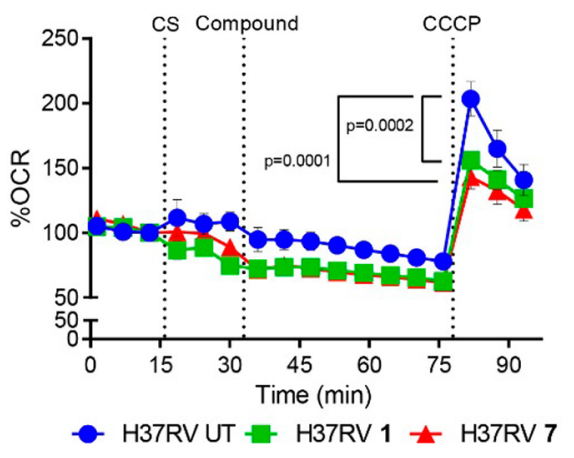

C

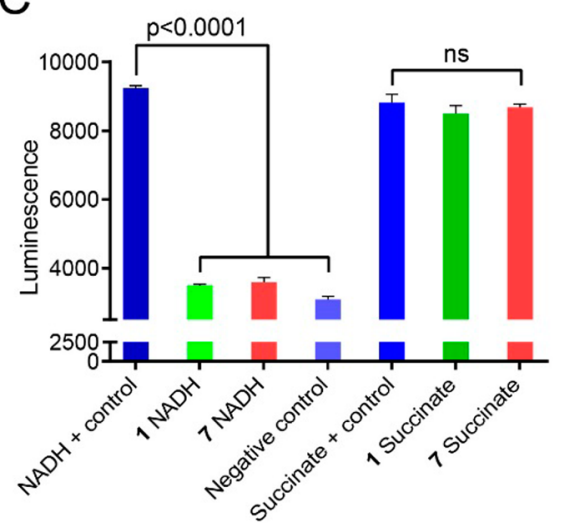

B
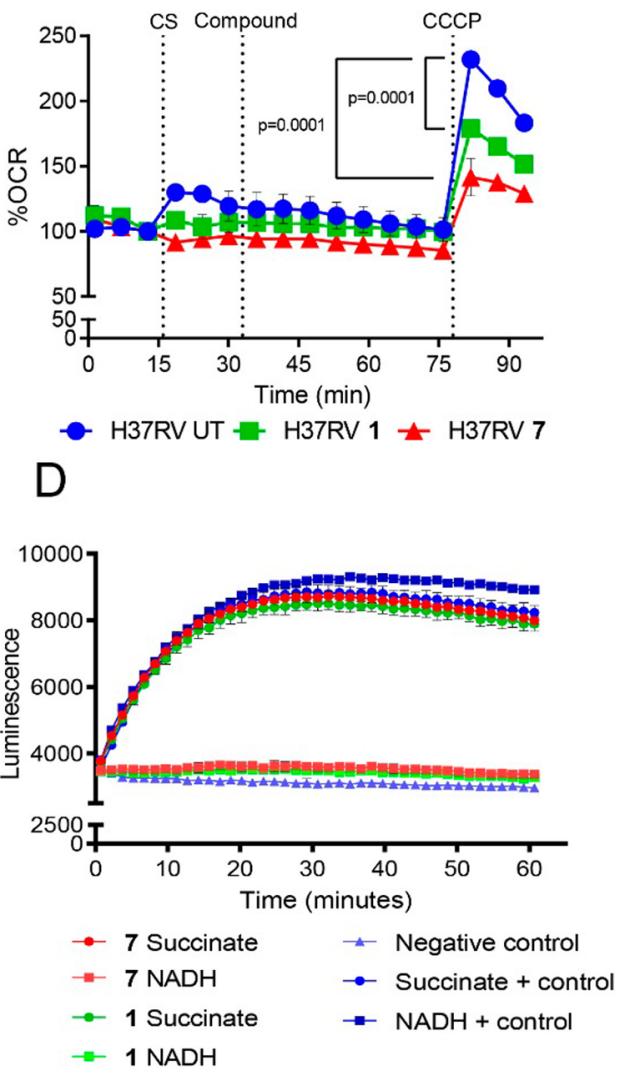

Figure 5. Mercapto-quinazolinones target Complex I of the MTb ETC. At the times indicated by the dotted vertical lines, either glucose (A) or palmitate (B) was added to $\mathrm{MTb}$ as carbon source (CS), followed by the mercapto-quinazolinones (Compound) and, last, the uncoupler CCCP to induce maximal respiration. The mercapto-quinazolinones diminished MTb's uncoupling capacity significantly compared to that of the untreated (UT) control. The oxygen consumption rate (OCR) is reported as a percentage of baseline values. Mercapto-quinazolinones inhibit ATP production in the presence of NADH but not succinate. (C, D) ATP production in inverted membrane vesicles (IMVs) in the presence of NADH or succinate as electron donors after $30 \mathrm{~min}$ (C) and over $60 \mathrm{~min}$ (D). P-values were calculated by one-way ANOVA using GraphPad Prism 7.02.

studies $^{21,36}$ have shown that $M T b$ can rapidly reroute electron flux to overcome inhibition of cytochrome $b c_{1}-a a_{3}$, cytochrome $b d$, or ATP synthase, resulting in enhanced respiration. Therefore, we speculated that the target of compounds 1 and 7 was at the point of entry into the electron transport chain (ETC), that is, Complex 1 (NADH dehydrogenase) or Complex II (succinate dehydrogenase). To test this prediction, ATP production was measured in $M T b$ inverted membrane vesicles (IMVs) in the presence of the mercapto-quinazolinones (Figure 5C,D). Notably, ATP production was significantly inhibited when $\mathrm{NADH}$ was provided as electron donor but not when succinate was the source of reducing equivalents, suggesting that the site of inhibition was $\mathrm{NADH}$ dehydrogenase. The mechanism by which the compounds interfere with $\mathrm{NADH}$ dehydrogenase function differs from clofazimine and the quinolinequinones, which have been proposed to interfere with electron transport by activating $\mathrm{NDH}-2$ resulting in production of reactive oxygen species. ${ }^{18,20}$

To verify that NDH-2 was indeed the target for this class of mercapto-quinazolinones, we expressed $M T b \mathrm{NDH}-2$ (MtNdh) encoded by the predicted essential $n d h$ in $E$. coli as a recombinant MBP-fusion protein and purified the protein to near homogeneity via amylose-resin affinity chromatography and gel filtration. The recombinant enzyme was highly active with coenzyme Q2 (ubiquinone Q-2) and $\mathrm{NADH}$ as substrates, delivering steadystate kinetic parameters similar to previously published results. ${ }^{37}$ Quinazolinones 1-3, 7, and 11 were found to have submicromolar
$\mathrm{IC}_{50}$ values against the MtNdh (Figure 6). Compounds 1, 7, and 11 showed the highest potency, with $\mathrm{IC}_{50}$ values from 7 to $26 \mathrm{nM}$,

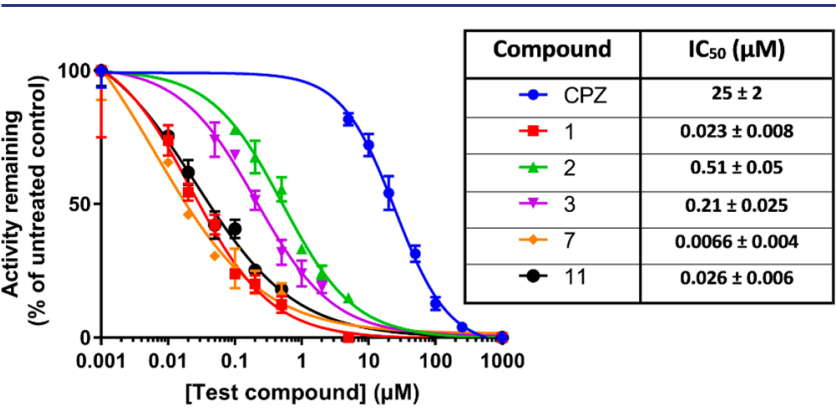

Figure 6. Inhibition of recombinant MBP-MtNdh by select quinazolinones. Steady-state enzyme activity was measured by monitoring absorbance changes at $340 \mathrm{~nm}$ due to NADH oxidation, as described in the Experimental Section. $\mathrm{NADH}$ and Q2 were fixed at 250 and $40 \mu \mathrm{M}$, respectively. Each data point is the mean \pm SD of at least 3 independent measurements. Inset table shows calculated $\mathrm{IC}_{50}$ values.

values 3-orders of magnitude lower than that for the previously characterized NDH-2 inhibitor chlorpromazine (CPZ; 10-25 $\mu \mathrm{M}$; Figure 6$)^{24}$ but superior to the quinolinyl pyrimidines discovered in a target-based screening effort against the $M T b \mathrm{NDH}-2 .{ }^{38}$ No timedependent inhibition was observed for these compounds. The mode of inhibition against MtNdh was further investigated using 

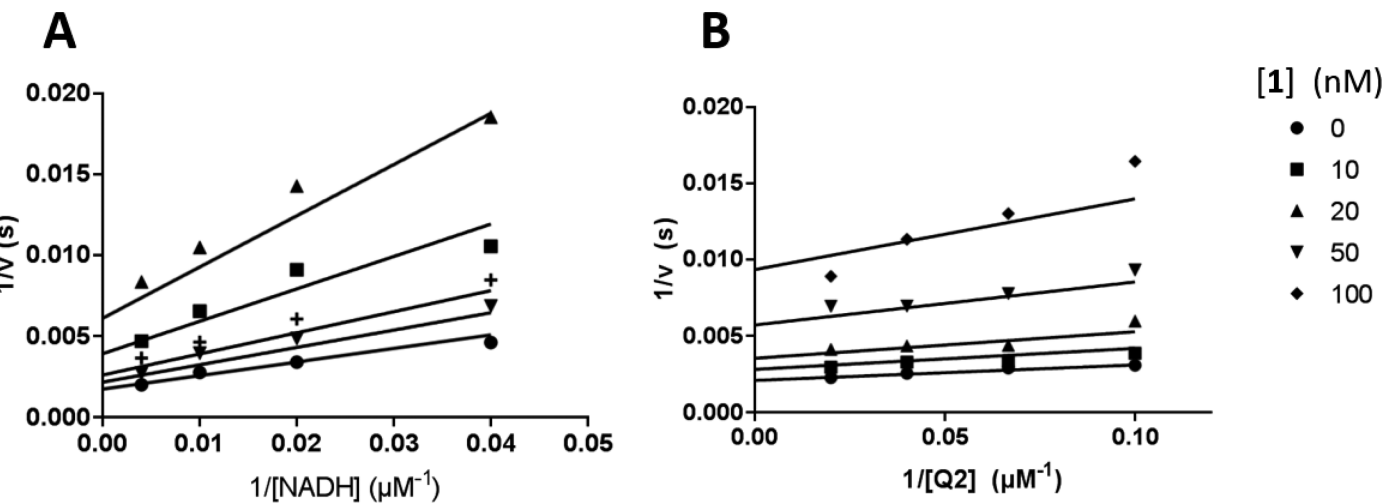

Figure 7. Double-reciprocal plot of inhibition kinetics of MBP-MtNdh by 1. NADH (left) or Q2 (right) concentrations were varied, in the presence of fixed concentrations of $40 \mu \mathrm{M}$ Q2 (A) or $250 \mu \mathrm{M} \mathrm{NADH}$ (B). Data points are the average of at least 3 independent measurements. Solid lines represent best-fit values of the data to the general Michaelis-Menten reversible inhibition equation, using nonlinear regression analysis.

compound 1: double reciprocal plots of enzyme activity under varying concentrations of 1 and either Q2 or NADH suggested patterns indicative of a noncompetitive mode of inhibition with both substrates ( $K_{\mathrm{i}}$ values of $\left.30-40 \mathrm{nM}\right)$, although the effect on slope was less evident when varying Q2 (Figure 7). This is similar to previous studies with a thiophenazine-based NDH-2 inhibitor ${ }^{39}$ and suggests that inhibition occurs through binding of the compound at an allosteric site, independent of the main substrate binding pockets.

In conclusion, the nonproton pumping type II NADH dehydrogenase (NDH-2) has been shown to play a critical role in the respiratory metabolism of bacteria. The 2-mercapto-quinazolinone scaffold is a potent inhibitor of the mycobacterial NDH-2, and although in this study $M T b$ whole-cell SAR only obtained limited improvement in potency, this information, together with the recently disclosed structural information on the enzyme from the bacterium Caldalkalibacillus thermarum, ${ }^{40}$ will aid in the future rational structure-based development of new and improved NDH-2 inhibitors. Critical for any structure-guided inhibitor design is an understanding of the ligand-binding pocket of the NDH-2 protein. The low amino acid identity between the $C$. thermarum and $M T b$ NDH-2 proteins (30\%) combined with the finding that this inhibitor likely binds to an allosteric site with no allosteric ligandbinding sites identified on the existing bacterial NDH-2 structure $^{40}$ suggests that cocrystallization of the compound with the $M T b$ NDH-2 protein will be essential to facilitate rational drug design. During revision of this paper, the SAR of a similar mercaptoquinazolinone scaffold ${ }^{41}$ was reported with a complementary paper describing the importance of the mycobacterial type II NADH dehydrogenase despite the nonessentiality of the individual $n d h$ and $n d h A$ genes. ${ }^{42}$

\section{EXPERIMENTAL SECTION}

Chemistry Summary. All commercially available reagents, solvents, and starting materials were purchased from Aldrich Chemical Co. (UK). Where necessary, a Biotage FLASH 25+ column chromatography system was used to purify mixtures; reagent-grade solvents used for chromatography were purchased from Fisher Scientific (UK), and flash column chromatography silica cartridges were obtained from Biotage (UK). Analytical thin-layer chromatography (TLC) was performed on precoated TLC plates (layer $0.20 \mathrm{~mm}$ silica gel 60 with fluorescent indicator UV254, from Merck). Developed plates were air-dried and analyzed under a UV lamp (UV 254/365 nm). Microwave irradiation was conducted using a BIOTAGE INITIATOR unit. The machine consists of a continuous focused microwave power delivery system with operator-selectable power output $(0-400 \mathrm{~W}$ at $2.45 \mathrm{GHz})$. All ${ }^{1} \mathrm{H}$ and ${ }^{13} \mathrm{C}$ NMR spectra were recorded on a Bruker ARX-500 spectrometer (500 and $300 \mathrm{MHz}$ for ${ }^{1} \mathrm{H}$ and ${ }^{13} \mathrm{C}$ NMR, respectively). Chemical shifts $(\delta)$ are reported in ppm relative to the residual solvent peak or internal standard (tetramethylsilane), and coupling constants $(J)$ are reported in hertz $(\mathrm{Hz})$. Data are reported as follows: chemical shift, multiplicity $(\mathrm{br}=$ broad, $\mathrm{s}=$ singlet, $\mathrm{d}=$ doublet, $\mathrm{t}=$ triplet, $\mathrm{m}=$ multiplet), and integration. LC-MS analyses were performed with either an Agilent HPLC 1100 series connected to a Bruker Daltonics MicrOTOF or an Agilent Technologies 1200 series HPLC connected to an Agilent Technologies 6130 quadrupole spectrometer, where both instruments were connected to an Agilent diode array detector. LC-MS chromatographic separations were conducted with a Waters X bridge C18 column, $50 \mathrm{~mm} \times 2.1 \mathrm{~mm}$, $3.5 \mu \mathrm{m}$ particle size; mobile phase of water/acetonitrile $+0.1 \%$ $\mathrm{HCOOH}$ or water/acetonitrile $+0.1 \% \mathrm{NH}_{3}$; linear gradient from $80: 20$ to $5: 95$ over $3.5 \mathrm{~min}$ and then held for $1.5 \mathrm{~min}$; flow rate of $0.5 \mathrm{~mL} \cdot \mathrm{min}^{-1}$. All assay compounds had a measured purity of $\geq 95 \%$ (by TIC and UV) as determined using this analytical LC-MS system. High resolution electrospray measurements were performed on a Bruker Daltonics MicrOTOF mass spectrometer.

General Method for the Preparation of Amide Coupling $(1,4-11,14-16,19-27)$. To a solution of 2-((4-oxo-3,4dihydroquinazolin-2-yl)thio)acetic acid (1.0 equiv) in a $1: 1$ ratio of acetonitrile $(1.5 \mathrm{~mL})$ and DMF $(1.5 \mathrm{~mL})$ were added $\mathrm{EDC} \cdot \mathrm{HCl}$ (1.0 equiv), HOAT (1.2 equiv), or HATU (1.0 equiv) and primary/secondary amine (1.0 equiv), and the mixture was stirred for $30 \mathrm{~min}$; DIPEA (2.0 equiv) was added to the reaction mixture and stirred at room temperature overnight. If a precipitate had formed this was filtered off, washed with acetonitrile, and airdried. If the reaction mixture had remained homogeneous, the solution was purified directly by preparative HPLC under acidic conditions, using $0.1 \% \mathrm{HCOOH}$ in water/acetonitrile (5-95\%) gradient elution to afford the product.

$N$-Cyclohexyl-2-((4-oxo-3,4-dihydroquinazolin-2-yl)thio)acetamide (1). To a solution of acid of 2-((4-oxo-3,4dihydroquinazolin-2-yl)thio)acetic acid (30) (500 mg, $2.1 \mathrm{mmol}$, 1.0 equiv) in $1: 1$ ratio of acetonitrile $(1.5 \mathrm{~mL})$ and $\mathrm{DMF}(1.5 \mathrm{~mL})$ were added $\mathrm{EDC} \cdot \mathrm{HCl}$ (1.2 equiv), HOAT (1.2 equiv), or HATU (804 mg, $2.1 \mathrm{mmol}, 1.0$ equiv) in DCM (3 mL) and cyclohexylamine (209 mg, $2.1 \mathrm{mmol}, 1.0$ equiv), and the mixture was stirred for $30 \mathrm{~min}$; DIPEA (0.73 mL, $2.1 \mathrm{mmol}, 2.0$ equiv) was added to the reaction mixture and stirred at room temperature 
overnight. The reaction mixture was purified by preparative HPLC under acidic conditions, using $0.1 \% \mathrm{HCOOH}$ in water/acetonitrile (5-95\%) gradient elution to afford a white solid of $\mathrm{N}$-cyclohexyl-2((4-oxo-3,4-dihydroquinazolin-2-yl)thio)acetamide as a white powder (450 mg, 66\% yield), $\mathrm{C}_{16} \mathrm{H}_{19} \mathrm{~N}_{3} \mathrm{O}_{2} \mathrm{~S}$, MW 317.41; ${ }^{1} \mathrm{H}$ NMR (500 MHz, DMSO) $\delta 12.66(\mathrm{brs}, 1 \mathrm{H}), 8.14(\mathrm{~d}, J=$ $7.9 \mathrm{~Hz}, 1 \mathrm{H}), 8.04(\mathrm{dd}, J=1.3,7.9 \mathrm{~Hz}, 1 \mathrm{H}), 7.80-7.76(\mathrm{~m}, 1 \mathrm{H})$, $7.50(\mathrm{~d}, J=7.9 \mathrm{~Hz}, 1 \mathrm{H}), 7.45-7.41(\mathrm{~m}, 1 \mathrm{H}), 3.92(\mathrm{~s}, 2 \mathrm{H}), 3.59-3.51$ $(\mathrm{m}, 1 \mathrm{H}), 1.76-1.64(\mathrm{~m}, 4 \mathrm{H}), 1.55(\mathrm{dd}, J=3.5,9.1 \mathrm{~Hz}, 1 \mathrm{H})$, $1.30-1.12(\mathrm{~m}, 5 \mathrm{H})$. LCMS $m / z 318.12[\mathrm{M}+1]^{+} 100 \%$. HRMS $(\mathrm{m} / z):[\mathrm{M}+\mathrm{H}]^{+}$calcd for $\mathrm{C}_{16} \mathrm{H}_{20} \mathrm{~N}_{3} \mathrm{O}_{2} \mathrm{~S}, 318.1270$; found, 318.1284 .

N-Cycloheptyl-2-((4-oxo-3,4-dihydroquinazolin-2-yl)thio)acetamide (4). White powder (21 mg, $23 \%$ yield), $\mathrm{C}_{17} \mathrm{H}_{21} \mathrm{~N}_{3} \mathrm{O}_{2} \mathrm{~S}$, MW 331.43; ${ }^{1} \mathrm{H}$ NMR (500 MHz, DMSO) $\delta 12.65$ (brs, $1 \mathrm{H}$ ), $8.26(\mathrm{~d}, J=7.8 \mathrm{~Hz}, 1 \mathrm{H}), 8.02(\mathrm{dd}, J=1.3,7.9 \mathrm{~Hz}, 1 \mathrm{H}), 7.77-7.72$ (m, $1 \mathrm{H}), 7.48-7.37(\mathrm{~m}, 2 \mathrm{H}), 3.88(\mathrm{~s}, 2 \mathrm{H}), 3.73$ (ddd, $J=4.2,8.6$, $16.9 \mathrm{~Hz}, 1 \mathrm{H}), 1.60-1.34(\mathrm{~m}, 12 \mathrm{H})$. LCMS $m / z 332.14[\mathrm{M}+1]^{+}$ $100 \%$. HRMS $(m / z):[\mathrm{M}+\mathrm{H}]^{+}$calcd for $\mathrm{C}_{17} \mathrm{H}_{22} \mathrm{~N}_{3} \mathrm{O}_{2} \mathrm{~S}$, 332.1427; found, 332.1439.

N-Cyclopentyl-2-((4-oxo-3,4-dihydroquinazolin-2-yl)thio)acetamide (5). White powder (39 mg, $24 \%$ yield), $\mathrm{C}_{15} \mathrm{H}_{17} \mathrm{~N}_{3} \mathrm{O}_{2} \mathrm{~S}$, MW 303.38; ${ }^{1} \mathrm{H}$ NMR (500 MHz, DMSO) $\delta 8.23$ (d, $J=$ $7.1 \mathrm{~Hz}, 1 \mathrm{H}), 8.04(\mathrm{dd}, J=1.3,8.0 \mathrm{~Hz}, 1 \mathrm{H}), 7.79-7.75(\mathrm{~m}, 1 \mathrm{H})$, $7.49(\mathrm{~d}, J=8.0 \mathrm{~Hz}, 1 \mathrm{H}), 7.45-7.41(\mathrm{~m}, 1 \mathrm{H}), 4.03-3.98(\mathrm{~m}, 1 \mathrm{H})$, $3.91(\mathrm{~s}, 2 \mathrm{H}), 1.82-1.76(\mathrm{~m}, 2 \mathrm{H}), 1.67-1.62(\mathrm{~m}, 2 \mathrm{H}), 1.53-1.36$ $(\mathrm{m}, 4 \mathrm{H})$. LCMS $m / z$ 304.12 $[\mathrm{M}+\mathrm{H}]^{+} 100 \%$. HRMS $(\mathrm{m} / z)$ : $[\mathrm{M}+\mathrm{H}]^{+}$calcd for $\mathrm{C}_{15} \mathrm{H}_{18} \mathrm{~N}_{3} \mathrm{O}_{2} \mathrm{~S}, 304.1114$; found, 304.1107 .

$\mathrm{N}$-Cyclobutyl-2-((4-oxo-3,4-dihydroquinazolin-2-yl)thio)acetamide (6). White powder (76 mg, $66 \%$ yield), $\mathrm{C}_{14} \mathrm{H}_{15} \mathrm{~N}_{3} \mathrm{O}_{2} \mathrm{~S}$, MW 289.35; ${ }^{1} \mathrm{H}$ NMR (400 MHz, DMSO) $\delta 12.67$ (s, 1H), 8.54 $(\mathrm{d}, J=7.7 \mathrm{~Hz}, 1 \mathrm{H}), 8.05-8.02(\mathrm{~m}, 1 \mathrm{H}), 7.81-7.75(\mathrm{~m}, 1 \mathrm{H}), 7.51$ (d, $J=8.1 \mathrm{~Hz}, 1 \mathrm{H}), 7.43(\mathrm{t}, J=7.5 \mathrm{~Hz}, 1 \mathrm{H}), 4.19$ (dd, $J=8.1$, $16.1 \mathrm{~Hz}, 1 \mathrm{H}), 3.91(\mathrm{~s}, 2 \mathrm{H}), 2.20-2.10(\mathrm{~m}, 2 \mathrm{H}), 1.97-1.85$ $(\mathrm{m}, 2 \mathrm{H}), 1.67-1.57(\mathrm{~m}, 2 \mathrm{H})$. LCMS $m / z 290.04[\mathrm{M}+\mathrm{H}]^{+}$ $100 \%$. HRMS $(m / z):[\mathrm{M}+\mathrm{H}]^{+}$calcd for $\mathrm{C}_{14} \mathrm{H}_{16} \mathrm{~N}_{3} \mathrm{O}_{2} \mathrm{~S}$, 290.0957; found, 290.0962.

$\mathrm{N}$-(4,4-Difluorocyclohexyl)-2-((4-oxo-3,4-dihydroquinazolin-2-yl)thio)acetamide (7). To a solution of 2-((4-oxo-3,4dihydroquinazolin-2-yl)thio)acetic acid $30(108 \mathrm{mg}, 0.4 \mathrm{mmol}$, 1.0 equiv) in DCM ( $3 \mathrm{~mL})$ were added HATU $(160 \mathrm{mg}, 0.4 \mathrm{mmol}$, 1.0 equiv) and 4,4-difluorocyclohexan-1-amine $(57 \mathrm{mg}$, $0.4 \mathrm{mmol}, 1.0$ equiv) and the mixture was stirred for $30 \mathrm{~min}$; DIPEA ( $0.074 \mathrm{~mL}, 0.4 \mathrm{mmol}, 2.0$ equiv) was added to the reaction mixture and stirred at room temperature overnight. The reaction mixture was purified by preparative HPLC under acidic conditions, using $0.1 \% \mathrm{HCOOH}$ in water/acetonitrile (5-95\%) gradient elution to afford a white solid of $\mathrm{N}$-(4,4-difluorocyclohexyl)-2-((4-oxo-3,4-dihydroquinazolin-2-yl)thio)acetamide as a white powder 7 (115 mg, 75\% yield), $\mathrm{C}_{16} \mathrm{H}_{17} \mathrm{~F}_{2} \mathrm{~N}_{3} \mathrm{O}_{2} \mathrm{~S}, \mathrm{MW}$ 353.39; ${ }^{1} \mathrm{H}$ NMR (500 MHz, DMSO) $\delta 12.64(\mathrm{~s}, 1 \mathrm{H}), 8.39$ (d, $J=$ $6.9 \mathrm{~Hz}, 1 \mathrm{H}), 8.02(\mathrm{dd}, J=1.2,7.9 \mathrm{~Hz}, 1 \mathrm{H}), 7.77-7.72(\mathrm{~m}, 1 \mathrm{H})$, $7.46(\mathrm{~d}, J=7.9 \mathrm{~Hz}, 1 \mathrm{H}), 7.40(\mathrm{t}, J=7.5 \mathrm{~Hz}, 1 \mathrm{H}), 3.90(\mathrm{~s}, 2 \mathrm{H})$, $3.77(\mathrm{t}, J=4.0 \mathrm{~Hz}, 1 \mathrm{H}), 2.04-1.75(\mathrm{~m}, 6 \mathrm{H}), 1.56-1.47(\mathrm{~m}, 2 \mathrm{H})$. LCMS $m / z 354.14[\mathrm{M}+\mathrm{H}]^{+} 100 \%$. HRMS $(m / z):[\mathrm{M}+\mathrm{H}]^{+}$ calcd for $\mathrm{C}_{16} \mathrm{H}_{18} \mathrm{~F}_{2} \mathrm{~N}_{3} \mathrm{O}_{2} \mathrm{~S}$, 354.1082; found, 354.1091.

$\mathrm{N}$-(4,4-Difluorocyclohexyl)-2-((4-oxo-3,4-dihydroquinazolin-2-yl)thio)acetamide $\mathrm{HCl}$ Salt Preparation (7). $\mathrm{N}-(4,4-$ Difluorocyclohexyl)-2-((4-oxo-3,4-dihydroquinazolin-2-yl)thio)acetamide (60 mg, $0.17 \mathrm{mmol}, 1.0$ equiv) in ethyl acetate $(10 \mathrm{~mL})$ and ethanol $(3 \mathrm{~mL})$ was heated up to $80^{\circ} \mathrm{C}$, until dissolved (90\%). The solution was cooled immediately, followed by the addition of $2 \mathrm{M} \mathrm{HCl}$ in diethyl ether ( $1 \mathrm{~mL}, 747 \mathrm{mg}, 20.49 \mathrm{mmol}, 120$ equiv) and stirred for a further $15 \mathrm{~min}$, where white precipitates were formed. The precipitate was filtered and dried to afford the $\mathrm{N}$-(4,4-difluorocyclohexyl)-2-((4-oxo-3,4-dihydroquinazolin-2-yl)thio)acetamide $\mathrm{HCl}$ salt ( $50 \mathrm{mg}, 75 \%$ yield), $\mathrm{C}_{16} \mathrm{H}_{17} \mathrm{~F}_{2} \mathrm{~N}_{3} \mathrm{O}_{2} \mathrm{~S} \cdot \mathrm{HCl}$, MW 389.85; ${ }^{1} \mathrm{H}$ NMR (500 MHz, DMSO) $\delta 8.32$ (d, $J=$ $7.6 \mathrm{~Hz}, 1 \mathrm{H}), 8.04$ (dd, $J=1.2,7.9 \mathrm{~Hz}, 1 \mathrm{H}), 7.80-7.76(\mathrm{~m}, 1 \mathrm{H})$, $7.49(\mathrm{~d}, J=7.8 \mathrm{~Hz}, 1 \mathrm{H}), 7.45-7.41(\mathrm{~m}, 1 \mathrm{H}), 3.95(\mathrm{~s}, 2 \mathrm{H})$, 2.52-2.50 (m, 1H), 2.05-1.99 (m, 2H), 1.97-1.76 (m, 4H), $1.57-1.48(\mathrm{~m}, 2 \mathrm{H})$. LCMS $m / z 354.14[\mathrm{M}+\mathrm{H}]^{+} 100 \%$. HRMS $(m / z):[\mathrm{M}+\mathrm{H}]^{+}$calcd for $\mathrm{C}_{16} \mathrm{H}_{18} \mathrm{~F}_{2} \mathrm{~N}_{3} \mathrm{O}_{2} \mathrm{~S}, 354.1082$; found, 354.1091 .

N-(2,2-Difluorocyclohexyl)-2-((4-oxo-3,4-dihydroquinazolin-2-yl)thio)acetamide (8). White powder (93 mg, 62\% yield), $\mathrm{C}_{16} \mathrm{H}_{17} \mathrm{~F}_{2} \mathrm{~N}_{3} \mathrm{O}_{3} \mathrm{~S}_{2}$, MW 353.39; ${ }^{1} \mathrm{H}$ NMR (500 MHz, DMSO) $\delta$ $12.64(\mathrm{~s}, 1 \mathrm{H}), 8.46(\mathrm{~d}, J=9.0 \mathrm{~Hz}, 1 \mathrm{H}), 8.04(\mathrm{~d}, J=7.9 \mathrm{~Hz}, 1 \mathrm{H})$, $7.79-7.75(\mathrm{~m}, 1 \mathrm{H}), 7.50(\mathrm{~d}, J=8.2 \mathrm{~Hz}, 1 \mathrm{H}), 7.43(\mathrm{dd}, J=$ $7.5 \mathrm{~Hz}, 1 \mathrm{H}), 4.03-4.01(\mathrm{~m}, 3 \mathrm{H}), 2.08-2.03(\mathrm{~m}, 1 \mathrm{H}), 1.86-1.63$ $(\mathrm{m}, 4 \mathrm{H}), 1.49-1.38(\mathrm{~m}, 3 \mathrm{H})$. LCMS $m / z 354.10[\mathrm{M}+\mathrm{H}]^{+}$ $100 \%$. HRMS $(m / z):[\mathrm{M}+\mathrm{H}]^{+}$calcd for $\mathrm{C}_{16} \mathrm{H}_{18} \mathrm{~F}_{2} \mathrm{~N}_{3} \mathrm{O}_{3} \mathrm{~S}_{2}$, 354.1082; found, 354.1094.

N-(3,3-Difluorocyclohexyl)-2-((4-oxo-3,4-dihydroquinazolin-2-yl)thio)acetamide (9). White powder ( $83 \mathrm{mg}, 55 \%$ yield), $\mathrm{C}_{16} \mathrm{H}_{17} \mathrm{~F}_{2} \mathrm{~N}_{3} \mathrm{O}_{3} \mathrm{~S}_{2}$, MW 353.39; ${ }^{1} \mathrm{H}$ NMR (500 MHz, DMSO) $\delta$ $12.61(\mathrm{brs}, 1 \mathrm{H}), 8.31(\mathrm{~d}, J=7.9 \mathrm{~Hz}, 1 \mathrm{H}), 8.04(\mathrm{dd}, J=1.3,7.9 \mathrm{~Hz}$, $1 \mathrm{H}), 7.80-7.76(\mathrm{~m}, 1 \mathrm{H}), 7.50(\mathrm{~d}, J=8.2 \mathrm{~Hz}, 1 \mathrm{H}), 7.43(\mathrm{t}, J=$ $7.5 \mathrm{~Hz}, 1 \mathrm{H}), 3.94(\mathrm{~s}, 2 \mathrm{H}), 3.91-3.75(\mathrm{~m}, 1 \mathrm{H}), 2.21-2.15$ (m, 1H), $1.98-1.95(\mathrm{~m}, 1 \mathrm{H}), 1.81-1.68(\mathrm{~m}, 4 \mathrm{H}), 1.45-1.24$ $(\mathrm{m}, 2 \mathrm{H})$. LCMS $m / z 354.10[\mathrm{M}+\mathrm{H}]^{+} 100 \%$. HRMS $(\mathrm{m} / z)$ : $[\mathrm{M}+\mathrm{H}]^{+}$calcd for $\mathrm{C}_{16} \mathrm{H}_{18} \mathrm{~F}_{2} \mathrm{~N}_{3} \mathrm{O}_{3} \mathrm{~S}_{2}, 354.1082$; found, 354.1095 .

$\mathrm{N}$-(Cyclohexylmethyl)-2-((4-oxo-3,4-dihydroquinazolin-2yl)thio)acetamide (10). White powder (34 mg, $25 \%$ yield), $\mathrm{C}_{17} \mathrm{H}_{21} \mathrm{~N}_{3} \mathrm{O}_{2} \mathrm{~S}$, MW 331.43; ${ }^{1} \mathrm{H}$ NMR (500 MHz, DMSO) $\delta$ $12.64(\mathrm{~s}, 1 \mathrm{H}), 8.16(\mathrm{~s}, 1 \mathrm{H}), 8.05-8.02(\mathrm{~m}, 1 \mathrm{H}), 7.79-7.75$ $(\mathrm{m}, 1 \mathrm{H}), 7.50(\mathrm{dd}, J=3.1,8.1 \mathrm{~Hz}, 1 \mathrm{H}), 7.44-7.40(\mathrm{~m}, 1 \mathrm{H}), 3.93$ (d, $J=2.5 \mathrm{~Hz}, 2 \mathrm{H}), 2.95-2.92(\mathrm{~m}, 2 \mathrm{H}), 1.67-1.58(\mathrm{~m}, 5 \mathrm{H})$, $1.38-1.34(\mathrm{~m}, 1 \mathrm{H}), 1.12-1.07(\mathrm{~m}, 3 \mathrm{H}), 0.87-0.79(\mathrm{~m}, 2 \mathrm{H})$. LCMS $m / z 332.21[\mathrm{M}+\mathrm{H}]^{+} 100 \%$. HRMS $(m / z):[\mathrm{M}+\mathrm{H}]^{+}$ calcd for $\mathrm{C}_{17} \mathrm{H}_{22} \mathrm{~N}_{3} \mathrm{O}_{2} \mathrm{~S}$, 332.1427; found, 332.1431.

$\mathrm{N}$-((4,4-Difluorocyclohexyl)methyl)-2-((4-oxo-3,4-dihydroquinazolin-2-yl)thio)acetamide (11). White powder (120 mg, $77 \%$ yield), $\mathrm{C}_{17} \mathrm{H}_{19} \mathrm{~N}_{3} \mathrm{~F}_{2} \mathrm{O}_{2} \mathrm{~S}$, MW 367.41; ${ }^{1} \mathrm{H}$ NMR (500 MHz, DMSO) $\delta 12.64(\mathrm{~s}, 1 \mathrm{H}), 8.27(\mathrm{t}, J=5.8 \mathrm{~Hz}, 1 \mathrm{H}), 8.04(\mathrm{dd}, J=$ $1.3,7.9 \mathrm{~Hz}, 1 \mathrm{H}), 7.80-7.76(\mathrm{~m}, 1 \mathrm{H}), 7.50(\mathrm{~d}, J=8.0 \mathrm{~Hz}, 1 \mathrm{H})$, 7.45-7.42 (m, 1H), $3.95(\mathrm{~s}, 2 \mathrm{H}), 3.02(\mathrm{t}, J=6.4 \mathrm{~Hz}, 2 \mathrm{H})$, $1.96-1.87(\mathrm{~m}, 2 \mathrm{H}), 1.74-1.52(\mathrm{~m}, 5 \mathrm{H}), 1.17-1.08(\mathrm{~m}, 2 \mathrm{H})$. LCMS $m / z 368.01[\mathrm{M}+\mathrm{H}]^{+} 100 \%$. HRMS $(m / z):[\mathrm{M}+\mathrm{H}]^{+}$ calcd for $\mathrm{C}_{17} \mathrm{H}_{20} \mathrm{~N}_{3} \mathrm{~F}_{2} \mathrm{O}_{2} \mathrm{~S}$, 368.1238; found, 368.1255.

$\mathrm{N}$-Cyclohexyl-N-methyl-2-((4-oxo-3,4-dihydroquinazolin2-yl)thio)acetamide (14). White powder (35 mg, 25\% yield), $\mathrm{C}_{17} \mathrm{H}_{21} \mathrm{~N}_{3} \mathrm{O}_{2} \mathrm{~S}$, MW 331.43; ${ }^{1} \mathrm{H}$ NMR (500 MHz, DMSO) $\delta$ 12.60 (brs, $1 \mathrm{H}), 8.04(\mathrm{dd}, J=1.6,7.9 \mathrm{~Hz}, 1 \mathrm{H}), 7.80-7.74$ $(\mathrm{m}, 1 \mathrm{H}), 7.49-7.40(\mathrm{~m}, 2 \mathrm{H}), 4.34(\mathrm{~s}, 1 \mathrm{H}), 4.23(\mathrm{~s}, 1 \mathrm{H})$, $3.80-3.76(\mathrm{~m}, 1 \mathrm{H}), 3.01(\mathrm{~s}, 2 \mathrm{H}), 2.74(\mathrm{~s}, 1 \mathrm{H}), 1.76(\mathrm{t}, J=$ $12.0 \mathrm{~Hz}, 3 \mathrm{H}), 1.62-1.52(\mathrm{~m}, 2 \mathrm{H}), 1.52-1.43(\mathrm{~m}, 2 \mathrm{H})$, $1.38-1.23(\mathrm{~m}, 2 \mathrm{H}), 1.15-1.05(\mathrm{~m}, 1 \mathrm{H})$. LCMS $\mathrm{m} / z 332.15$ $[\mathrm{M}+\mathrm{H}]^{+}$. HRMS $(m / z):[\mathrm{M}+\mathrm{H}]^{+}$calcd for $\mathrm{C}_{17} \mathrm{H}_{22} \mathrm{~N}_{3} \mathrm{O}_{2} \mathrm{~S}$, 332.1427; found, 332.1440.

2-((4-Oxo-3,4-dihydroquinazolin-2-yl)thio)propanoic Acid (56). To a solution of 2-thioxo-2,3-dihydroquinazolin4(1H)-one 29 (500 mg, $2.8 \mathrm{mmol}, 1.0$ equiv) were added 2-bromopropanoic acid (557 mg, $3.6 \mathrm{mmol}, 1.3$ equiv) and triethylamine ( $2.3 \mathrm{~mL}, 16.8 \mathrm{mmol}, 6.0$ equiv) in DMF $(5 \mathrm{~mL})$, and the mixture was stirred for $12 \mathrm{~h}$ at $75^{\circ} \mathrm{C}$. Once the reaction 
has completed, it was poured onto crushed ice and acidified with $1 \mathrm{~N} \mathrm{HCl}$, where the product precipitated out of the solution. The precipitate was filtered and dried to yield 2-((4-oxo-3,4dihydroquinazolin-2-yl)thio)propanoic acid 56 (548 mg, 78\% yield), $\mathrm{C}_{11} \mathrm{H}_{10} \mathrm{~N}_{2} \mathrm{O}_{3} \mathrm{~S}$, MW 250.27; ${ }^{1} \mathrm{H}$ NMR (500 MHz, DMSO) $\delta$ $12.66(\mathrm{~s}, 1 \mathrm{H}), 8.04(\mathrm{q}, J=3.10 \mathrm{~Hz}, 1 \mathrm{H}), 7.70(\mathrm{~m}, 1 \mathrm{H}), 7.50(\mathrm{~d}, J=$ $8.00 \mathrm{~Hz}, 1 \mathrm{H}), 7.44(\mathrm{~m}, 1 \mathrm{H}), 4.57(\mathrm{q}, J=7.3 \mathrm{~Hz}, 2 \mathrm{H}), 1.55(\mathrm{~d}, J=$ $7.30 \mathrm{~Hz}, 3 \mathrm{H})$. LCMS $m / z 251.00[\mathrm{M}+\mathrm{H}]^{+} 100 \%$.

$\mathrm{N}$-Cyclohexyl-2-((4-oxo-3,4-dihydroquinazolin-2-yl)thio)propanamide (15). White powder (45 $\mathrm{mg}$, 35\% yield), $\mathrm{C}_{17} \mathrm{H}_{21} \mathrm{~N}_{3} \mathrm{O}_{2} \mathrm{~S}$, MW 331.43; ${ }^{1} \mathrm{H}$ NMR (500 MHz, DMSO) $\delta$ 12.59 (brs, $1 \mathrm{H}), 8.17(\mathrm{~d}, J=7.7 \mathrm{~Hz}, 1 \mathrm{H}), 8.04(\mathrm{dd}, J=1.4,7.9 \mathrm{~Hz}$, $1 \mathrm{H}), 7.81-7.77(\mathrm{~m}, 1 \mathrm{H}), 7.53(\mathrm{~d}, J=8.2 \mathrm{~Hz}, 1 \mathrm{H}), 7.45-7.42$ $(\mathrm{m}, 1 \mathrm{H}), 4.54(\mathrm{q}, J=7.0 \mathrm{~Hz}, 1 \mathrm{H}), 3.56-3.48(\mathrm{~m}, 1 \mathrm{H}), 1.76-1.61$ $(\mathrm{m}, 4 \mathrm{H}), 1.53-1.50(\mathrm{~m}, 4 \mathrm{H}), 1.29-1.10(\mathrm{~m}, 5 \mathrm{H})$. LCMS $m / z$ $332.10[\mathrm{M}+\mathrm{H}]^{+} 100 \%$. HRMS $(m / z):[\mathrm{M}+\mathrm{H}]^{+}$calcd for $\mathrm{C}_{17} \mathrm{H}_{22} \mathrm{~N}_{3} \mathrm{O}_{2} \mathrm{~S}, 332.1427$; found, 332.1432.

N-Cyclohexyl-N-methyl-2-((4-oxo-3,4-dihydroquinazolin2-yl)thio)propanamide (16). White powder (40 mg, 29\% yield), $\mathrm{C}_{18} \mathrm{H}_{23} \mathrm{~N}_{3} \mathrm{O}_{2} \mathrm{~S}$, MW 345.46; ${ }^{1} \mathrm{H}$ NMR (500 MHz, DMSO) $\delta$ 12.60 (brs, $1 \mathrm{H}), 8.07-8.02(\mathrm{~m}, 1 \mathrm{H}), 7.82-7.75(\mathrm{~m}, 1 \mathrm{H})$, $7.50-7.41(\mathrm{~m}, 2 \mathrm{H}), 4.24-4.18(\mathrm{~m}, 1 \mathrm{H}), 3.05(\mathrm{~s}, 2 \mathrm{H}), 2.75(\mathrm{~s}, 1 \mathrm{H})$, $1.80-1.70(\mathrm{~m}, 3 \mathrm{H}), 1.64-1.54(\mathrm{~m}, 1 \mathrm{H}), 1.54-1.47(\mathrm{~m}, 6 \mathrm{H})$, $1.36-1.20(\mathrm{~m}, 2 \mathrm{H}), 1.14-1.02(\mathrm{~m}, 2 \mathrm{H})$. LCMS $\mathrm{m} / z 346.10$ $[\mathrm{M}+\mathrm{H}]^{+} 100 \%$. HRMS $(\mathrm{m} / z):[\mathrm{M}+\mathrm{H}]^{+}$calcd for $\mathrm{C}_{18} \mathrm{H}_{24} \mathrm{~N}_{3} \mathrm{O}_{2} \mathrm{~S}$, 346.1584; found, 346.1608 .

$\mathrm{N}$-Cyclohexylglycine (53). Cyclohexylamine 51 (100 mg, $1.0 \mathrm{mmol}, 1.0$ equiv) and ethyl 2-hydroxyacetate $\mathbf{5 2}(104.9 \mathrm{mg}$, $1.0 \mathrm{mmol}, 61.0$ equiv) were stirred neat in a round-bottom flask for $12 \mathrm{~h}$. The solvent of the crude mixture was evaporated completely, and the residue was purified via flash column chromatography eluting with $10 \% \mathrm{DCM}$ in methanol to afford $\mathrm{N}$-Cyclohexylglycine $\mathbf{5 3}$ (100 mg, 63\% yield), $\mathrm{C}_{8} \mathrm{H}_{15} \mathrm{NO}_{2}, \mathrm{MW}$ 157.21 ; ${ }^{1} \mathrm{H}$ NMR (500 MHz, DMSO) $\delta 6.34$ (brs, $1 \mathrm{H}$ ), 4.05-4.04 (m, 2H), 3.82-3.77 (m, 1H), 3.77-3.69 (m, 1H), $1.86-1.83(\mathrm{q}, J=5.28 \mathrm{~Hz}, 2 \mathrm{H}), 1.67-1.63(\mathrm{~m}, 2 \mathrm{H}), 1.57-1.53$ $(\mathrm{m}, 1 \mathrm{H}), 1.35-1.26(\mathrm{~m}, 2 \mathrm{H}), 1.15-1.07(\mathrm{~m}, 3 \mathrm{H})$. LCMS $\mathrm{m} / z$ $158.21[\mathrm{M}+\mathrm{H}]^{+} 100 \%$.

2-(Methylthio)quinazolin-4(3H)-one (54). A solution of iodomethane (398 mg, $2.8 \mathrm{mmol}, 1.0$ equiv) in methanol $(8 \mathrm{~mL})$ was added slowly to a closed vessel containing a solution of 2-thioxo2,3-dihydroquinazolin-4( $1 \mathrm{H})$-one 29 ( $500 \mathrm{mg}, 2.8 \mathrm{mmol}, 1.0$ equiv) in $1 \%$ aqueous $\mathrm{NaOH}(8 \mathrm{~mL})$ under $\mathrm{N}_{2}$ atmosphere and stirred for $1 \mathrm{~h}$ at room temperature. The reaction mixture was then cooled to $0^{\circ} \mathrm{C}$, and the $\mathrm{pH}$ was adjusted to 7 with an aqueous solution of $1 \mathrm{~N} \mathrm{HCl}$. The solvent was removed under reduced pressure, and the solid was filtered, washed with water/methanol, and dried to afford 2-(methylthio)quinazolin-4(3H)-one 54 (532 mg, 98\% yield), $\mathrm{C}_{9} \mathrm{H}_{8} \mathrm{~N}_{2} \mathrm{OS}$, MW 192.24; ${ }^{1} \mathrm{H}$ NMR (500 MHz, DMSO) $\delta 12.62(\mathrm{~s}, 1 \mathrm{H}), 8.09(\mathrm{q}, J=3.13 \mathrm{~Hz}, 1 \mathrm{H}), 7.81(\mathrm{~m}, 1 \mathrm{H})$, $7.59(\mathrm{~d}, J=8.10 \mathrm{~Hz}, 1 \mathrm{H}), 7.47(\mathrm{~m}, 1 \mathrm{H}), 2.63(\mathrm{~s}, 3 \mathrm{H})$. LCMS $m / z$ $193.18[\mathrm{M}+\mathrm{H}]^{+} 100 \%$.

$\mathrm{N}$-Cyclohexyl-2-((4-oxo-3,4-dihydroquinazolin-2-yl)amino)acetamide (17). 2-Amino- $N$-cyclohexyl-acetamide 55 (40.63 mg, $0.26 \mathrm{mmol}, 1.0$ equiv), 2-(methylthio)quinazolin$4(3 \mathrm{H})$-one 54 ( $50 \mathrm{mg}, 0.26 \mathrm{mmol}, 1.0$ equiv) were suspended in ethyl acetate $(2 \mathrm{~mL})$ in a sealed microwave vial and irradiated $(0-400 \mathrm{~W}$ at $2.65 \mathrm{GHz})$ at $140^{\circ} \mathrm{C}$ for $2 \mathrm{~h}$. Upon completion, the reaction was filtered and the filtrate was extracted with diethyl ether to afford $\mathrm{N}$-cyclohexyl-2-((4-oxo-3,4-dihydroquinazolin-2yl)amino)acetamide as a white powder 17 (4.4 mg, $4.4 \%$ yield), $\mathrm{C}_{16} \mathrm{H}_{20} \mathrm{~N}_{4} \mathrm{O}_{2}$, MW 300.36; ${ }^{1} \mathrm{H}$ NMR (500 MHz, DMSO) $\delta 8.10$ $(\mathrm{d}, J=7.7 \mathrm{~Hz}, 1 \mathrm{H}), 7.58-7.56(\mathrm{~m}, 1 \mathrm{H}), 7.33(\mathrm{~d}, J=8.7 \mathrm{~Hz}, 1 \mathrm{H})$, $7.22-7.18(\mathrm{~m}, 1 \mathrm{H}), 3.95(\mathrm{~s}, 2 \mathrm{H}), 1.76-1.66(\mathrm{~m}, 4 \mathrm{H}), 1.56-1.53$ (m, 1H), 1.31-1.07 (m, 6H). LCMS $m / z 301.0[\mathrm{M}+\mathrm{H}]^{+} 100 \%$. HRMS $(m / z):[\mathrm{M}+\mathrm{H}]^{+}$calcd for $\mathrm{C}_{16} \mathrm{H}_{21} \mathrm{~N}_{4} \mathrm{O}_{2}, 301.1659$; found, 301.1665 .

$\mathrm{N}$-Cyclohexyl-2-((4-oxo-3,4-dihydroquinazolin-2-yl)oxy)acetamide (18). 2-(Methylthio)quinazolin-4(3H)-one 54 (50 mg, $0.26 \mathrm{mmol}, 1.0$ equiv) and $N$-cyclohexylglycine 53 ( $21.7 \mathrm{mg}, 0.12 \mathrm{mmol}, 1.0$ equiv) were dissolved in THF $(2 \mathrm{~mL})$ and heated to $80^{\circ} \mathrm{C}$. Upon reaction completion, the crude product was directly purified via prep-HPLC Gilson purification using $0.1 \%$ ammonia in water/acetonitrile 5-95\% gradient elution to afford the product as a white powder 18 (10 mg, 24\% yield), $\mathrm{C}_{16} \mathrm{H}_{19} \mathrm{~N}_{3} \mathrm{O}_{3}$, MW 301.34; ${ }^{1} \mathrm{H}$ NMR (500 MHz, DMSO) $\delta 12.36$ (brs, $1 \mathrm{H}), 8.03$ (d, $J=7.7 \mathrm{~Hz}, 1 \mathrm{H}), 7.9$ (d, 1H), 7.73 (d, $J=$ $8.7 \mathrm{~Hz}, 1 \mathrm{H}), 7.40-7.33(\mathrm{~m}, 1 \mathrm{H}), 3.77(\mathrm{~s}, 2 \mathrm{H}), 3.60-3.56$ $(\mathrm{m}, 1 \mathrm{H}), 1.76-1.66(\mathrm{~m}, 4 \mathrm{H}), 1.57-1.53(\mathrm{~m}, 1 \mathrm{H}), 1.31-1.10$ $(\mathrm{m}, 6 \mathrm{H})$. LCMS $m / z$ 302.1 $[\mathrm{M}+\mathrm{H}]^{+} 100 \%$. HRMS $(\mathrm{m} / z)$ : $[\mathrm{M}+\mathrm{H}]^{+}$calcd for $\mathrm{C}_{16} \mathrm{H}_{20} \mathrm{~N}_{3} \mathrm{O}_{32}, 302.1499$; found, 302.1487 .

$\mathrm{N}$-Cyclohexyl-3-(4-oxo-3,4-dihydroquinazolin-2-yl)propanamide (19). White powder (110 mg, $80 \%$ yield), $\mathrm{C}_{17} \mathrm{H}_{21} \mathrm{~N}_{3} \mathrm{O}_{2}$, MW 299.37; ${ }^{1} \mathrm{H}$ NMR (500 MHz, DMSO) $\delta$ $12.18(\mathrm{~s}, 1 \mathrm{H}), 8.08(\mathrm{dd}, J=1.3,7.9 \mathrm{~Hz}, 1 \mathrm{H}), 7.85-7.76(\mathrm{~m}, 2 \mathrm{H})$, $7.56(\mathrm{~d}, J=8.0 \mathrm{~Hz}, 1 \mathrm{H}), 7.48-7.45(\mathrm{~m}, 1 \mathrm{H}), 3.55-3.48(\mathrm{~m}, 1 \mathrm{H})$, $2.83(\mathrm{t}, J=7.4 \mathrm{~Hz}, 2 \mathrm{H}), 2.58(\mathrm{t}, J=7.4 \mathrm{~Hz}, 2 \mathrm{H}), 1.73-1.64$ $(\mathrm{m}, 4 \mathrm{H}), 1.55-1.52(\mathrm{~m}, 1 \mathrm{H}), 1.28-1.09(\mathrm{~m}, 5 \mathrm{H})$. LCMS $\mathrm{m} / z$ $300.10[\mathrm{M}+\mathrm{H}]^{+} 100 \%$. HRMS $(\mathrm{m} / z):[\mathrm{M}+\mathrm{H}]^{+}$calcd for $\mathrm{C}_{17} \mathrm{H}_{22} \mathrm{~N}_{3} \mathrm{O}_{2}, 300.1707$; found, 300.1721 .

2-((3-Methyl-4-oxo-3,4-dihydroquinazolin-2-yl)thio)acetic Acid (50). 2-Mercapto-3-methylquinazolin-4(3H)-one 49 (220 mg, $1.14 \mathrm{mmol}, 1.0$ equiv), 2-bromoacetic acid (206 mg, $1.48 \mathrm{mmol}, 1.3$ equiv), and triethylamine $(0.95 \mathrm{~mL}, 6.8 \mathrm{mmol}$, 6.0 equiv) were stirred in DMF $(5 \mathrm{~mL})$ for $12 \mathrm{~h}$ at $75^{\circ} \mathrm{C}$. Upon reaction completion, the reaction mixture was poured onto crushed ice and acidified with $1 \mathrm{~N} \mathrm{HCl}$. The precipitate formed was collected and dried to afford the product 2-((3-methyl-4-oxo-3,4dihydroquinazolin-2-yl)thio)acetic acid $\mathbf{5 0}$ (250 mg, 87\% yield), as a white powder, $\mathrm{C}_{11} \mathrm{H}_{10} \mathrm{~N}_{2} \mathrm{O}_{3} \mathrm{~S}$, MW 250.27; ${ }^{1} \mathrm{H} \mathrm{NMR}(500 \mathrm{MHz}$, DMSO) $\delta 12.89(\mathrm{~s}, 1 \mathrm{H}), 8.08(\mathrm{q}, J=3.05 \mathrm{~Hz}, 1 \mathrm{H}), 7.79(\mathrm{~m}, 1 \mathrm{H})$, $7.46(\mathrm{~m}, 2 \mathrm{H}), 4.11(\mathrm{~s}, 2 \mathrm{H}), 3.55(\mathrm{~s}, 3 \mathrm{H})$. LCMS $\mathrm{m} / z 251.04$ $[\mathrm{M}+\mathrm{H}]^{+} 100 \%$.

N-Cyclohexyl-2-((3-methyl-4-oxo-3,4-dihydroquinazolin2-yl)thio)acetamide (20). White powder (20 mg, $15 \%$ yield), $\mathrm{C}_{17} \mathrm{H}_{21} \mathrm{~N}_{3} \mathrm{O}_{2} \mathrm{~S}$, MW 331.42; ${ }^{1} \mathrm{H}$ NMR (500 MHz, DMSO) $\delta 8.15$ $(\mathrm{d}, J=7.9 \mathrm{~Hz}, 1 \mathrm{H}), 8.08(\mathrm{~d}, J=7.9 \mathrm{~Hz}, 1 \mathrm{H}), 7.82-7.78(\mathrm{~m}, 1 \mathrm{H})$, $7.52(\mathrm{~d}, J=8.2 \mathrm{~Hz}, 1 \mathrm{H}), 7.47-7.43(\mathrm{~m}, 1 \mathrm{H}), 3.98(\mathrm{~s}, 2 \mathrm{H}), 3.54$ $(\mathrm{s}, 4 \mathrm{H}), 1.76-1.65(\mathrm{~m}, 4 \mathrm{H}), 1.55(\mathrm{~d}, J=12.8 \mathrm{~Hz}, 1 \mathrm{H}), 1.28-1.11$ $(\mathrm{m}, 5 \mathrm{H})$. LCMS $m / z 332.15[\mathrm{M}+\mathrm{H}]^{+} 100 \%$. HRMS $(\mathrm{m} / z)$ : $[\mathrm{M}+\mathrm{H}]^{+}$calcd for $\mathrm{C}_{17} \mathrm{H}_{22} \mathrm{~N}_{3} \mathrm{O}_{2} \mathrm{~S}, 332.1427$; found, 332.1436 .

2-(Quinazolin-2-ylthio)acetic Acid (44). 2-Chloroquinazoline $43(0.2 \mathrm{~g}, 1.22 \mathrm{mmol})$ and sodium thioglycolic acid 39b ( 1 equiv) were dissolved in DMF, and triethylamine (6.0 equiv) was added. The reaction mixture was heated to $100^{\circ} \mathrm{C}$ overnight. The resulting precipitate was filtered and used without any further purification to afford the product 2-(quinazolin-2-ylthio)acetic acid $44(0.153 \mathrm{~g}, 57 \%$ yield $)$ as a white powder, $\mathrm{C}_{10} \mathrm{H}_{8} \mathrm{~N}_{2} \mathrm{O}_{2} \mathrm{~S}$, MW 220.25; ${ }^{1} \mathrm{H}$ NMR (500 MHz, DMSO) $\delta 9.41(\mathrm{~d}, J=1.5 \mathrm{~Hz}$, $1 \mathrm{H}), 8.09(\mathrm{~m}, 1 \mathrm{H}), 7.95-7.93(\mathrm{~m}, 1 \mathrm{H}), 7.79-7.77(\mathrm{~m}, 1 \mathrm{H})$, 7.66-7.61 (m, 1H), $4.05(\mathrm{~s}, 2 \mathrm{H})$. LCMS $m / z 221.1[\mathrm{M}+\mathrm{H}]^{+}$ $100 \%$.

N-Cyclohexyl-2-(quinazolin-2-ylthio)acetamide (21). White powder (21 mg, 10\% yield), $\mathrm{C}_{16} \mathrm{H}_{19} \mathrm{~N}_{3} \mathrm{OS}$, MW 301.41; ${ }^{1} \mathrm{H}$ NMR $(300 \mathrm{MHz}, \mathrm{DMSO}) \delta 9.36(\mathrm{~m}, 1 \mathrm{H}), 8.05-8.0(\mathrm{~m}, 2 \mathrm{H})$, 7.79-7.76 (m, 1H), 3.95 (s, 2H), 3.52-3.48 (m, 1H), 2.49-2.48 
(m, $2 \mathrm{H}), 1.72-1.32(\mathrm{~m}, 5 \mathrm{H}), 1.25-1.21(\mathrm{~m}, 3 \mathrm{H})$. LCMS $m / z$ $302.1[\mathrm{M}+\mathrm{H}]^{+} 100 \%$.

2-((4-Aminoquinazolin-2-yl)thio)acetic Acid (46). 2-Chloroquinazolin-4-amine $45(0.2 \mathrm{~g}, 1.11 \mathrm{mmol}, 1.0$ equiv), sodium thioglycolic acid $39 \mathrm{~b}(0.103 \mathrm{~g}, 1.11 \mathrm{mmol}, 1.0$ equiv $)$, and triethylamine were dissolved in DMF $(2 \mathrm{~mL})(0.93 \mathrm{~mL}, 6.68 \mathrm{mmol}$, 6.0 equiv). The reaction mixture was heated to $100{ }^{\circ} \mathrm{C}$ overnight. The resulting precipitate was filtered to afford a white powder (0.2 g, 76\% yield) and used without further purification. LCMS (ESI) $m / z 236.1[\mathrm{M}+\mathrm{H}]^{+}$

2-((4-Aminoquinazolin-2-yl)thio)- $N$-cyclohexylacetamide (22). White powder (21 mg, $10 \%$ yield), $\mathrm{C}_{16} \mathrm{H}_{20} \mathrm{~N}_{4} \mathrm{OS}, \mathrm{MW}$ 316.42; ${ }^{1} \mathrm{H}$ NMR (300 MHz, DMSO) $\delta 8.13(\mathrm{dd}, J=3.0,6.0 \mathrm{~Hz}$, $1 \mathrm{H}), 7.97$ (d, $J=6 \mathrm{~Hz}, 1 \mathrm{H}), 7.87$ (brs, $2 \mathrm{H}), 7.77-7.69(\mathrm{~m}, 1 \mathrm{H})$, 7.51-7.49 (m, 1H), 7.38-7.34 (m, 1H), $3.75(\mathrm{~s}, 2 \mathrm{H}), 3.55-3.45$ (m, $1 \mathrm{H}), 1.76-1.47(\mathrm{~m}, 5 \mathrm{H}), 1.23-1.09(\mathrm{~m}, 5 \mathrm{H})$. LCMS $m / z$ $317.1[\mathrm{M}+\mathrm{H}]^{+} 100 \%$.

2-((4-Oxo-3,4,5,6,7,8-hexahydroquinazolin-2-yl)thio)acetic Acid (40). 2-Sulfanyl-5,6,7,8-tetrahydro-4-quinazolinol 38 ( $0.1 \mathrm{~g}, 5.49 \mathrm{mmol}, 1.0$ equiv), chloroacetic acid $39 \mathrm{a}$ ( 1.3 equiv), and triethylamine ( 6 equiv) were stirred in DMF at room temperature overnight. Once the reaction was complete, the reaction mixture was poured over crushed ice and acidified with $1 \mathrm{~N} \mathrm{HCl}$. The white precipitate was collected by filtration and washed with water to afford the product as a white powder ( $750 \mathrm{mg}$, $58 \%$ yield) which was used without further purification, $\mathrm{C}_{10} \mathrm{H}_{12} \mathrm{~N}_{2} \mathrm{O}_{3} \mathrm{~S}$, MW 240.28; ${ }^{1} \mathrm{H}$ NMR (300 MHz, DMSO) $\delta 12.59$ (brs, $\left.1 \mathrm{H}\right), 3.93(\mathrm{~s}, 2 \mathrm{H})$, $2.45(\mathrm{t}, J=3.0 \mathrm{~Hz}, 2 \mathrm{H}), 2.29(\mathrm{t}, J=3.0 \mathrm{~Hz}, 2 \mathrm{H}), 1.70-1.63$ (m, 4H). LCMS (ESI) $m / z 239.1[\mathrm{M}-\mathrm{H}]^{+} 100 \%$.

N-Cyclohexyl-2-((4-oxo-3,4,5,6,7,8-hexahydroquinazolin2-yl)thio)acetamide (23). White powder ( $43 \mathrm{mg}, 17 \%$ yield), $\mathrm{C}_{16} \mathrm{H}_{23} \mathrm{~N}_{3} \mathrm{O}_{2} \mathrm{~S}$, MW 321.44; ${ }^{1} \mathrm{H}$ NMR (300 MHz, DMSO) $\delta$ 12.47 (brs, $1 \mathrm{H}), 8.00$ (brs, $1 \mathrm{H}), 3.80(\mathrm{~s}, 2 \mathrm{H}), 3.58-3.49(\mathrm{~m}, 1 \mathrm{H})$, $2.47(\mathrm{t}, J=3.0 \mathrm{~Hz}, 2 \mathrm{H}), 2.31(\mathrm{t}, J=3.0 \mathrm{~Hz}, 2 \mathrm{H}), 1.75-1.54$ $(\mathrm{m}, 9 \mathrm{H}), 1.29-1.13(\mathrm{~m}, 5 \mathrm{H})$. LCMS $m / z 320.1[\mathrm{M}-\mathrm{H}]^{+} 100 \%$. 2-((4-Oxo-4,5,6,7-tetrahydro-3H-cyclopenta[d]pyrimidin2-yl)thio)acetic acid (42). 2-Thioxo-1,2,3,5,6,7-hexahydro-4Hcyclopenta[d]pyrimidin-4-one 41 ( $1.0 \mathrm{~g}, 5.94 \mathrm{mmol}, 1.0$ equiv), chloroacetic acid 39a (1.3 equiv), and triethylamine (6 equiv) were stirred in DMF $(2 \mathrm{~mL})$ at room temperature overnight. Once the reaction was complete, it was poured over crushed ice and acidified with $1 \mathrm{~N} \mathrm{HCl}$. The white precipitate was collected by filtration and washed with water to afford the product as a white powder (800 mg, 59\% yield), which was used without further purification, $\mathrm{C}_{9} \mathrm{H}_{10} \mathrm{~N}_{2} \mathrm{O}_{3} \mathrm{~S}$, MW 226.05; ${ }^{1} \mathrm{H}$ NMR (300 MHz, DMSO) $\delta 12.65($ brs, $1 \mathrm{H}), 3.96(\mathrm{~s}, 2 \mathrm{H}), 2.71(\mathrm{t}, J=3.0 \mathrm{~Hz}, 2 \mathrm{H})$, $2.58(\mathrm{t}, J=3.0 \mathrm{~Hz}, 2 \mathrm{H}), 1.97-1.93(\mathrm{~m}, 2 \mathrm{H})$. LCMS $m / z 227.1$ $[\mathrm{M}+\mathrm{H}]^{+} 100 \%$.

$\mathrm{N}$-Cyclohexyl-2-((4-oxo-4,5,6,7-tetrahydro-3H-cyclopenta[d]pyrimidin-2-yl)thio)acetamide(24). White powder (59 mg, $22 \%$ yield), $\mathrm{C}_{15} \mathrm{H}_{23} \mathrm{~N}_{3} \mathrm{O}_{2} \mathrm{~S}$, MW 307.41; ${ }^{1} \mathrm{H}$ NMR (300 MHz, DMSO) $\delta 12.59$ (brs, $1 \mathrm{H}), 8.03(\mathrm{~s}, 1 \mathrm{H}), 3.84(\mathrm{~s}, 2 \mathrm{H}), 3.58-3.49$ $(\mathrm{m}, 1 \mathrm{H}), 2.71(\mathrm{t}, J=3.0 \mathrm{~Hz}, 2 \mathrm{H}), 2.60(\mathrm{t}, J=3.0 \mathrm{~Hz}, 2 \mathrm{H})$, 2.0-1.92 (m, 2H), 1.75-1.52 (m, 5H), $1.29-1.16(\mathrm{~m}, 5 \mathrm{H})$. LCMS (ESI) $m / z 308.1[\mathrm{M}+\mathrm{H}]^{+} 100 \%$.

2-((4,5-Dimethyl-6-oxo-1,6-dihydropyrimidin-2-yl)thio)acetic Acid (48). 5,6-Dimethyl-2-thiouracil 47 (0.5 g, $3.20 \mathrm{mmol})$, chloroacetic acid 39a $(0.39 \mathrm{~g}, 4.16 \mathrm{mmol})$, and triethylamine $(2.62 \mathrm{~mL}, 1.94 \mathrm{mmol})$ were stirred in DMF $(2 \mathrm{~mL})$ at room temperature overnight. Once the reaction was complete, it was poured over crushed ice and acidified with $1 \mathrm{~N} \mathrm{HCl}$. The white precipitate was collected by filtration and washed with water to afford the product as a white powder ( $0.36 \mathrm{~g}$, 54\% yield) which was used without further purification, $\mathrm{C}_{8} \mathrm{H}_{10} \mathrm{~N}_{2} \mathrm{O}_{3} \mathrm{~S}$, MW 214.24; ${ }^{1} \mathrm{H}$ NMR (300 MHz, DMSO) $\delta 12.56$ (brs, $\left.1 \mathrm{H}\right), 3.89(\mathrm{~s}, 2 \mathrm{H})$, 2.14 (s, 3H), 1.85 (s, 3H). LCMS (ESI) $m / z 213.1[\mathrm{M}-\mathrm{H}]$; HPLC purity $98 \%$.

N-Cyclohexyl-2-((4,5-dimethyl-6-oxo-1,6-dihydropyrimidin-2-yl)thio)acetamide (25). White powder ( $0.047 \mathrm{~g}, 17 \%$ yield), $\mathrm{C}_{14} \mathrm{H}_{21} \mathrm{~N}_{3} \mathrm{O}_{2} \mathrm{~S}$, MW 295.40; ${ }^{1} \mathrm{H}$ NMR (400 MHz, DMSO- $\left.d_{6}\right) \delta$ 7.99 (dd, $J=20.3,8.1 \mathrm{~Hz}, 1 \mathrm{H}), 3.80(\mathrm{~s}, 2 \mathrm{H}), 3.11-2.97(\mathrm{~m}, 1 \mathrm{H})$, $2.20(\mathrm{~s}, 3 \mathrm{H}), 1.89(\mathrm{~s}, 3 \mathrm{H}), 1.78-1.64(\mathrm{~m}, 5 \mathrm{H}), 1.33-1.12$ (m, 5H). LCMS (ESI) $m / z 296.1[\mathrm{M}+\mathrm{H}]^{+} 100 \%$.

6-Fluoro-2-thioxo-2,3-dihydroquinazolin-4(1H)-one (33). 2-Amino-5-fluorobenzoic acid 32 ( $1 \mathrm{~g}, 6.5 \mathrm{mmol}, 1.0$ equiv) and thiourea $(2.1 \mathrm{~g}, 25.8 \mathrm{mmol}, 6.0$ equiv) were heated neat in a round-bottom flask to $180{ }^{\circ} \mathrm{C}$ for $3 \mathrm{~h}$ with stirring. The reaction was cooled, and $25 \mathrm{~mL}$ of water was added. After stirring for $10 \mathrm{~min}$, the formed precipitate was filtered off, washed with cold water, and dried to afford 6-fluoro-2-thioxo-2,3-dihydroquinazolin-4 $(1 \mathrm{H})$-one 33 (0.45 g, 35.9\% yield) as a yellow powder, $\mathrm{C}_{8} \mathrm{H}_{5} \mathrm{FN}_{2} \mathrm{OS}, \mathrm{MW}$ 196.2; ${ }^{1} \mathrm{H}$ NMR (500 MHz, DMSO) $\delta 9.72(\mathrm{~s}, 1 \mathrm{H}), 7.51-7.39$ $(\mathrm{m}, J=8.5 \mathrm{~Hz}, 1 \mathrm{H}), 7.37-7.30(\mathrm{~m}, J=8.6 \mathrm{~Hz}, 1 \mathrm{H}), 7.19-7.16$ $(\mathrm{m}, J=8.85 \mathrm{~Hz}, 1 \mathrm{H})$. LCMS $m / z 197.78[\mathrm{M}+\mathrm{H}]^{+} 100 \%$.

2-((6-Fluoro-4-oxo-3,4-dihydroquinazolin-2-yl)thio)acetic Acid (34). 6-Fluoro-2-thioxo-2,3-dihydroquinazolin-4( $1 \mathrm{H})$ one 33 (414 mg, $2.1 \mathrm{mmol}, 1.0$ equiv), 2-bromoacetic acid (586.39 mg, $4.2 \mathrm{mmol}, 2.0$ equiv), and triethylamine $(1.76 \mathrm{~mL}$, $12.6 \mathrm{mmol}, 6.0$ equiv) were stirred in $\operatorname{DMF}(5 \mathrm{~mL})$ at $75^{\circ} \mathrm{C}$ for $12 \mathrm{~h}$. Upon reaction completion, the reaction mixture was poured over crushed ice and acidified with $1 \mathrm{~N} \mathrm{HCl}$. The precipitate was filtered and dried to afford 2-((6-fluoro-4-oxo-3,4-dihydroquinazolin-2-yl)thio)acetic acid 34 (150 mg, 27.9\% yield), $\mathrm{C}_{10} \mathrm{H}_{7} \mathrm{FN}_{2} \mathrm{O}_{3} \mathrm{~S}$, MW 254.24; ${ }^{1} \mathrm{H}$ NMR (500 MHz, DMSO) $\delta$ $12.88(\mathrm{~s}, 1 \mathrm{H}), 7.72(\mathrm{q}, J=3.87 \mathrm{~Hz}, 1 \mathrm{H}), 7.65(\mathrm{~m}, 1 \mathrm{H}), 7.54(\mathrm{q}, J=$ $4.62 \mathrm{~Hz}, 1 \mathrm{H}), 4.03(\mathrm{~s}, 2 \mathrm{H})$. LCMS $m / z 254.10[\mathrm{M}+\mathrm{H}]^{+} 100 \%$.

$\mathrm{N}$-(4,4-Difluorocyclohexyl)-2-((6-fluoro-4-oxo-3,4-dihydroquinazolin-2-yl)thio)acetamide (26). To a solution of 2-((6fluoro-4-oxo-3,4-dihydroquinazolin-2-yl)thio)acetic acid 34 (100 mg, $0.39 \mathrm{mmol}, 1.0$ equiv) in a $1: 1$ ratio of acetonitrile $(1.5 \mathrm{~mL})$ and DMF $(1.5 \mathrm{~mL})$ were added $\mathrm{EDC} \cdot \mathrm{HCl}(90 \mathrm{mg}$, $0.74 \mathrm{mmol}, 1.2$ equiv), HOAT ( $64 \mathrm{mg}, 0.47 \mathrm{mmol}, 1.2$ equiv), and 4,4-difluorocyclohexan-1-amine (67 mg, $0.39 \mathrm{mmol}, 1.0$ equiv), and the mixture was stirred for $30 \mathrm{~min}$. DIPEA $(0.13 \mathrm{~mL}$, $0.78 \mathrm{mmol}, 2.0$ equiv) was added, and the resulting mixture was stirred at room temperature overnight. The crude mixture was purified by preparative HPLC under acidic conditions, using $0.1 \%$ $\mathrm{HCOOH}$ in water/acetonitrile (5-95\%) gradient elution to afford $\mathrm{N}$-(4,4-difluorocyclohexyl)-2-((6-fluoro-4-oxo-3,4-dihydroquinazolin-2-yl)thio)acetamide as a white powder $26(12 \mathrm{mg}$, $8.2 \%$ yield), $\mathrm{C}_{16} \mathrm{H}_{16} \mathrm{~N}_{3} \mathrm{~F}_{3} \mathrm{O}_{2} \mathrm{~S}$, MW 371.86; ${ }^{1} \mathrm{H}$ NMR (500 MHz, DMSO) $\delta 12.76$ (brs, $1 \mathrm{H}), 8.39-8.36(\mathrm{~m}, 1 \mathrm{H}), 7.71-7.60$ $(\mathrm{m}, 2 \mathrm{H}), 7.52(\mathrm{dd}, J=5.0,8.9 \mathrm{~Hz}, 1 \mathrm{H}), 3.88(\mathrm{~s}, 2 \mathrm{H}), 3.77(\mathrm{~d}, J=$ $8.5 \mathrm{~Hz}, 1 \mathrm{H}), 2.08-1.77(\mathrm{~m}, 6 \mathrm{H}), 1.55-1.47$ (m, 2H). LCMS $m / z 372.3[\mathrm{M}+\mathrm{H}]^{+} 100 \%$. HRMS $(\mathrm{m} / z):[\mathrm{M}+\mathrm{H}]^{+}$calcd for $\mathrm{C}_{16} \mathrm{H}_{17} \mathrm{~N}_{3} \mathrm{~F}_{3} \mathrm{O}_{2} \mathrm{~S}$, 372.0988; found, 372.0987.

2-Thioxo-2,3-dihydropyrido[3,4-d]pyrimidin-4(1H)-one (36). 2-Aminopyridine-4-carboxylic acid 35 (1 g, $7.2 \mathrm{mmol}$, 1.0 equiv) and thiourea ( $2.8 \mathrm{~g}, 36.2 \mathrm{mmol}, 5.0$ equiv) were heated neat in a round-bottom flask to $180^{\circ} \mathrm{C}$ for $3 \mathrm{~h}$ with stirring. The reaction was cooled, and $25 \mathrm{~mL}$ of water was added. After stirring for $10 \mathrm{~min}$, the formed precipitate was filtered off, washed with cold water, and dried to afford 2-thioxo-2,3-dihydropyrido[3,4d] pyrimidin-4 $(1 \mathrm{H})$-one $36(1.11 \mathrm{~g}, 85 \%$ yield $)$ as a yellow powder, $\mathrm{C}_{7} \mathrm{H}_{5} \mathrm{FN}_{2} \mathrm{OS}$, MW 179.2; ${ }^{1} \mathrm{H}$ NMR (500 MHz, DMSO) $\delta$ 
12.89 (brs, $1 \mathrm{H}), 12.70$ (brs, $1 \mathrm{H}), 8.73$ (s, $1 \mathrm{H}), 8.49$ (d, $J=4.85 \mathrm{~Hz}$, $1 \mathrm{H}), 7.79(\mathrm{~d}, J=0.80 \mathrm{~Hz}, 1 \mathrm{H})$. LCMS $m / z 180.11[\mathrm{M}+\mathrm{H}]^{+} 100 \%$.

2-((4-Oxo-3,4-dihydropyrido[3,4-d]pyrimidin-2-yl)thio)acetic Acid (37). 2-Thioxo-2,3-dihydropyrido[3,4-d]pyrimidin4(1H)-one 36 ( $500 \mathrm{mg}, 2.79 \mathrm{mmol}, 1.0$ equiv), 2-bromoacetic acid (775.39 mg, $5.5 \mathrm{mmol}, 2.0$ equiv), and triethylamine $(2.33 \mathrm{~mL}$, $16.7 \mathrm{mmol}, 6.0$ equiv) were stirred in $\mathrm{DMF}(5 \mathrm{~mL})$ at $75^{\circ} \mathrm{C}$ for $12 \mathrm{~h}$. Upon reaction completion, the reaction mixture was poured over crushed ice and acidified with $1 \mathrm{~N} \mathrm{HCl}$, and the precipitate was collected and dried to afford 2-((4-oxo-3,4-dihydropyrido$[3,4-d]$ pyrimidin-2-yl)thio)acetic acid 37 (600 mg, 90.6\% yield), $\mathrm{C}_{9} \mathrm{H}_{7} \mathrm{~N}_{3} \mathrm{O}_{3} \mathrm{~S}$, MW 237.24; ${ }^{1} \mathrm{H}$ NMR (500 MHz, DMSO) $\delta 12.89$ $(\mathrm{s}, 1 \mathrm{H}), 8.85(\mathrm{~d}, J=0.65 \mathrm{~Hz}, 1 \mathrm{H}), 8.57(\mathrm{~d}, J=5.00 \mathrm{~Hz}, 1 \mathrm{H}), 7.88$ $(\mathrm{d}, J=0.80 \mathrm{~Hz}, 1 \mathrm{H}), 4.08(\mathrm{~s}, 2 \mathrm{H})$. LCMS $m / z 238.15[\mathrm{M}+\mathrm{H}]^{+}$ $100 \%$.

$\mathrm{N}$-(4,4-Difluorocyclohexyl)-2-((4-oxo-3,4-dihydropyrido[3,4-d]pyrimidin-2-yl)thio)acetamide (27). White powder (64 mg, 42\% yield), $\mathrm{C}_{15} \mathrm{H}_{16} \mathrm{~N}_{4} \mathrm{O}_{2} \mathrm{~F}_{2} \mathrm{~S}, \mathrm{MW} 354.38 ;{ }^{1} \mathrm{H}$ NMR $(500 \mathrm{MHz}, \mathrm{DMSO}) \delta 13.02(\mathrm{~s}, 1 \mathrm{H}), 8.86(\mathrm{~s}, 1 \mathrm{H}), 8.57(\mathrm{~d}, J=$ $5.2 \mathrm{~Hz}, 1 \mathrm{H}), 8.29(\mathrm{~d}, J=7.4 \mathrm{~Hz}, 1 \mathrm{H}), 7.87(\mathrm{~d}, J=5.0 \mathrm{~Hz}, 1 \mathrm{H})$, $3.98(\mathrm{~s}, 2 \mathrm{H}), 3.31(\mathrm{~s}, 1 \mathrm{H}), 2.09-1.99(\mathrm{~m}, 2 \mathrm{H}), 1.98-1.86$ (m, 2H), 1.86-1.77 (m, 2H), 1.58-1.48 (m, 2H). LCMS $m / z$ $355.22[\mathrm{M}+\mathrm{H}]^{+} 100 \%$. HRMS $(\mathrm{m} / z):[\mathrm{M}+\mathrm{H}]^{+}$calcd for $\mathrm{C}_{15} \mathrm{H}_{17} \mathrm{~N}_{4} \mathrm{O}_{2} \mathrm{~F}_{2} \mathrm{~S}$, 355.1034; found, 355.1033.

Intrinsic Clearance (Cli) Experiments. Test compound $(0.5 \mu \mathrm{M})$ was incubated with female CD1 mouse liver microsomes (Xenotech LLC; $0.5 \mathrm{mg} / \mathrm{mL}, 50 \mathrm{mM}$ potassium phosphate buffer, $\mathrm{pH} 7.4)$, and the reaction started with addition of excess NADPH $(8 \mathrm{mg} / \mathrm{mL}, 50 \mathrm{mM}$ potassium phosphate buffer, $\mathrm{pH}$ 7.4). Immediately, at time zero, and then at 3, 6, 9, 15, and $30 \mathrm{~min}$, an aliquot $(50 \mu \mathrm{L})$ of the incubation mixture was removed and mixed with acetonitrile $(100 \mu \mathrm{L})$ to stop the reaction. Internal standard was added to all samples; the samples were centrifuged to sediment precipitated protein, and the plates were then sealed prior to UPLC-MS/MS analysis using a Quattro Premier XE (Waters Corporation, USA). XLfit (IDBS, UK) was used to calculate the exponential decay and consequently the rate constant $(k)$ from the ratio of peak area of test compound to internal standard at each time point. The rate of intrinsic clearance $(\mathrm{Cli})$ of each test compound was then calculated using the following calculation.

$$
\mathrm{CLi}(\mathrm{mL} / \mathrm{min} / \mathrm{g} \text { liver })=k \times V \times \text { microsomal protein yield }
$$

where $V(\mathrm{~mL} / \mathrm{mg}$ protein $)$ is the incubation volume $/ \mathrm{mg}$ protein added and microsomal protein yield is taken as $52.5 \mathrm{mg}$ protein $/ \mathrm{g}$ liver. Verapamil $(0.5 \mu \mathrm{M})$ was used as a positive control to confirm acceptable assay performance.

Aqueous Solubility. The aqueous solubility of the test compounds was measured using laser nephelometry. Compounds were subject to serial dilution from 10 to $0.5 \mathrm{mM}$ in DMSO. An aliquot was then mixed with Milli-Q water to obtain an aqueous dilution plate with a final concentration range of $250-12 \mu \mathrm{M}$, with a final DMSO concentration of $2.5 \%$. Triplicate aliquots were transferred to a flat bottomed polystyrene plate which was immediately read on the NEPHELOstar (BMG Lab Technologies). The amount of laser scatter caused by insoluble particulates (relative nephelometry units, RNU) was plotted against compound concentration using a segmental regression fit, with the point of inflection being quoted as the compounds aqueous solubility $(\mu \mathrm{M})$.

CHI LogD Determination. The chromatographic hydrophobicity index $(\mathrm{CHI})$ was determined according the method previously described. ${ }^{43,44}$ Briefly, test compounds were prepared as $0.5 \mathrm{mM}$ solutions in 50:50 acetonitrile/water and analyzed by reversed-phase HPLC-UV (wavelength $254 \mathrm{~nm}$ ) using a Phenomenex Luna C18 $100 \AA$, $150 \times 4.6 \mathrm{~mm}, 5 \mu \mathrm{m}$ column with a gradient of aqueous phase $(50 \mathrm{mM}$ ammonium acetate $(\mathrm{pH} \mathrm{7.4)})$ and mobile phase (acetonitrile). By plotting the retention time of a set of reference compounds against known $\mathrm{CHI}$ values, the $\mathrm{CHI}$ value of test compounds was calculated according to their retention time.

Plasma Protein Binding Experiments. In brief, a 96-well equilibrium dialysis apparatus was used to determine the free fraction in plasma for each compound (HT Dialysis LLC, Gales Ferry, CT). Membranes (12-14 kDaA cutoff) were conditioned in deionized water for $60 \mathrm{~min}$, followed by conditioning in 80:20 deionized water/ethanol overnight and then rinsed in water and isotonic buffer before use. Mouse plasma from appropriate species was removed from the freezer and allowed to thaw on the day of experiment. Thawed plasma was then centrifuged (Allegra X12-R, Beckman Coulter, USA) and spiked with test compound (final concentration $10 \mu \mathrm{g} / \mathrm{mL}$ ), and $150 \mu \mathrm{L}$ aliquots $(n=3$ replicate determinations) were loaded into the 96-well equilibrium dialysis plate. Dialysis against isotonic buffer $(150 \mu \mathrm{L})$ was carried out for $5 \mathrm{~h}$ in a temperature controlled incubator at ca. $37^{\circ} \mathrm{C}$ (Barworld scientific Ltd., UK) using an orbital microplate shaker at $100 \mathrm{rpm}$ (Barworld scientific Ltd., UK). At the end of the incubation period, $50 \mu \mathrm{L}$ aliquots of plasma or buffer were transferred into a 96-well deep plate and the composition in each well was balanced with control fluid $(50 \mu \mathrm{L})$, such that the volume of buffer to plasma is the same. Sample extraction was performed by the addition of $200 \mu \mathrm{L}$ of acetonitrile containing an appropriate internal standard. Samples were allowed to mix for $1 \mathrm{~min}$ and then centrifuged at $3000 \mathrm{rpm}$ in 96-well blocks for 15 min (Allegra X12-R, Beckman Coulter, USA) after which $150 \mu \mathrm{L}$ of supernatant was removed to $50 \mu \mathrm{L}$ of water. All samples were analyzed by UPLC-MS/MS on a Quattro Premier XE Mass Spectrometer (Waters Corporation, USA). The unbound fraction was determined as the ratio of the peak area in buffer to that in plasma.

PAMPA Assay. The permeability was performed using a 96well precoated BD Gentest PAMPA plate (BD Biosciences, U.K.). Each well was divided into two chambers: donor and acceptor, separated by a lipid-oil-lipid trilayer constructed in a porous filter. The effective permeability, $\mathrm{Pe}$, of the compound was measured at $\mathrm{pH}$ 7.4. Stock solutions $(5 \mathrm{mM})$ of the compound were prepared in DMSO. The compound was then further diluted to $10 \mu \mathrm{M}$ in phosphate buffered saline at $\mathrm{pH}$ 7.4. The final DMSO concentration did not exceed $5 \% \mathrm{v} / \mathrm{v}$. The compound dissolved in phosphate buffered saline was then added to the donor side of the membrane, and phosphate buffered saline without compound was added to the acceptor side. The PAMPA plate was left at room temperature for $5 \mathrm{~h}$; after which time, an aliquot $(100 \mu \mathrm{L})$ was then removed from both acceptor and donor compartments and mixed with acetonitrile $(80 \mu \mathrm{L})$ containing an internal standard: donepezil at $50 \mathrm{ng} / \mathrm{mL})$. The samples were centrifuged $\left(10 \mathrm{~min}, 5^{\circ} \mathrm{C}, 3270 \mathrm{~g}\right)$ to sediment precipitated protein and sealed prior to UPLC-MS/MS analysis using a Quattro Premier XE (Waters Corp, USA). Pe was calculated as shown in the below equation.

$$
\begin{gathered}
\operatorname{Pe}(\mathrm{nm} / \mathrm{s})=107 \times-\ln [1-\mathrm{CA}(t) / \text { Cequi }] \\
{[A \times(1 / \mathrm{VD}+1 / \mathrm{VA}) \times t]}
\end{gathered}
$$

where $\mathrm{CA}(t)=$ peak area of compound present in acceptor well at time $(t)=18000 \mathrm{~s}$; Cequi $=[\mathrm{CD}(t) \times \mathrm{VD}+\mathrm{CA}(t) \times \mathrm{VA}] /$ $(\mathrm{VD}+\mathrm{VA}) ; A=$ filter area; $\mathrm{VD}=$ donor well volume; $\mathrm{VA}=$ acceptor 
well volume; $t=$ incubation time; $\operatorname{CD}(t)=$ peak area of compound present in donor well at time $(t)=18000 \mathrm{~s}$. Recovery of compound from donor and acceptor wells was calculated, and data was only accepted when recovery exceeded $70 \%$.

Animal Care Assurance. All mouse studies performed at the University of Dundee were performed under the authority of a project license (PPL70/8346) issued by the Home Office under the Animals (Scientific Procedures) Act 1986, as amended in 2012 (and in compliance with EU Directive EU/2010/63). License applications are approved by the University's Ethical Review Committee (ERC) before submission to the Home Office. The ERC develops and oversees policy on all aspects of the use of animals on University premises and is a subcommittee of the University Court, its highest governing body.

Mouse Pharmacokinetics. Test compound was dosed as a bolus solution intravenously at $3 \mathrm{mg}$ free base $/ \mathrm{kg}$ (dose volume: $5 \mathrm{~mL} / \mathrm{kg}$; dose vehicle: $10 \%$ DMSO; 40\% PEG400; 50\% saline) to female $\mathrm{C} 57 \mathrm{Bl} / 6$ mice $(n=3)$ or dosed orally by gavage as a suspension at 10 or at 5,30 , or $100 \mathrm{mg}$ free base $/ \mathrm{kg}$ (dose volume: $10 \mathrm{~mL} / \mathrm{kg}$; dose vehicle: $1.0 \%$ carboxy methyl cellulose) to female $\mathrm{C} 57 \mathrm{Bl} / 6$ mice $(n=3 /$ dose level). Blood samples were taken from each mouse tail vein at predetermined time points postdose, mixed with nine volumes of distilled water, and stored frozen until UPLC-MS/MS analysis. Pharmacokinetic parameters were derived from the blood concentration time curve using PK Solutions software v 2.0 (Summit Research Services, USA).

Strains and Media. Mycobacterium tuberculosis $\mathrm{H} 37 \mathrm{Rv}$ (ATCC 27294) was used for all work with this organism unless otherwise indicated. The activity of the compound on cell wall synthesis and the $b c_{1}$ complex was measured using the piniBAC reporter strain and the $c y d C$ :: aph strains, respectively, using previously described methods. ${ }^{35,45}$ Broth-based medium (7H9/ADC/Tw) for $\mathrm{MTb}$ consisted of Middlebrook $7 \mathrm{H} 9$ (Becton Dickinson) supplemented with 10\% ADC [albumin $(50 \mathrm{~g} / \mathrm{L}) /$ dextrose $(20 \mathrm{~g} / \mathrm{L}) / \mathrm{NaCl}(8.1 \mathrm{~g} / \mathrm{L})], 0.2 \%$ glycerol] and $0.05 \%$ Tween 80 . Solid growth medium for MTb was Middlebrook 7H11 (Becton Dickinson) supplemented with OADC [ADC with $0.06 \%$ oleic acid]. Potencies of compounds by MIC determination were performed as previously described. ${ }^{45}$ The $\Delta n d h A$ strain was generated by insertion of the aph gene into the native Bam $\mathrm{HI}$ restriction site 873 nucleotides downstream of the start codon using the previously described suicide vector method ${ }^{46}$ to effect legitimate recombination in MTb.

Measurement of Intracellular ATP Levels. $M T b \mathrm{H} 37 \mathrm{Rv}$ was grown to early log phase (OD650 nm of 0.2 ) and diluted 20fold in the same medium (7H9/ADC/Tw). $100 \mu \mathrm{L}$ aliquots of cells were added to each well of sterile white polystyrene 96-well plates (Corning Inc., Corning, NY) containing $2 \mu \mathrm{L}$ drug dilutions in DMSO in triplicate. ATP was measured at different time points as indicated by a bioluminescent assay using the BacTiterGlo reagent (Promega, Madison, WI) as recommended by the manufacturer.

Bioenergetics. The extracellular flux analysis assays were performed as described previously. ${ }^{21,36}$ In short, M. tuberculosis $\mathrm{H} 37 \mathrm{Rv}$ were grown in $7 \mathrm{H} 9$ (10\% OADC, $0.01 \%$ tyloxapol) to an OD of 0.8 . Bacilli were pelleted, suspended in unbuffered carbonsource-free XF 7H9 media, and seeded into the XF culture plate, at a density of $2 \times 10^{6}$ bacilli/well. During the XF screen, the oxygen consumption rate (OCR) was measured, noninvasively and in real time. OCR data points are representative of the average OCR during $3 \mathrm{~min}$ of continuous measurement in the transient microchamber, with the error being calculated from the
OCR measurements taken from eight replicate wells by the Wave Desktop 2.3 software (Agilent). During the assay carbon sources (glucose and palmitate at a final concentration of $0.2 \%$ ), the mercapto-quinazolinones (Compounds 1 and 7 at final concentrations of 39 and $45 \mu \mathrm{M}$, respectively) and CCCP (final concentration of $3 \mu \mathrm{M}$ ) were added to the assay media at the indicated time.

Inverted Membrane Vesicle (IMV). IMVs were isolated, and the ATP generation assay was performed as described previously. ${ }^{36}$ In brief, $M T b \mathrm{mc}^{2} 6230$ (cultured in $7 \mathrm{H} 9,0.01 \%$ tyloxapol, $10 \%$ OADC, $0.2 \%$ casamino acids, and $24 \mu \mathrm{g} / \mathrm{mL}$ pantothenic acid) were collected via centrifugation, incubated with lysozyme, and lysed via bead beating in a buffer containing $10 \mathrm{mM}$ HEPES, $50 \mathrm{mM} \mathrm{KCl}, 5 \mathrm{mM} \mathrm{MgCl}_{2}$, and $10 \%$ glycerol. IMVs were isolated by differential centrifugation. The ATP synthesis assay was performed using a Roche Bioluminescence Assay Kit CL II. Membrane vesicles were provided either $250 \mu \mathrm{M}$ $\mathrm{NADH}$ or $1 \mathrm{mM}$ succinate as an electron donor, $50 \mu \mathrm{M} \mathrm{ADP}$, and $5 \mathrm{mM}$ phosphate in the above buffer containing the luciferase/ luciferin reagents. Luminescence was measured in a 384-well plate using a BioTek Synergy H4 plate reader.

Recombinant Rv1854c Purification. The ORF corresponding to Rv1854c was codon optimized for E. coli, synthesized (ThermoFisher), and cloned between the NcoI and HindIII sites of pMALc5x, affording a vector for the IPTGinducible overexpression of $\mathrm{MtNdh}$ with an $\mathrm{N}$-terminal maltosebinding protein (MBP) fusion tag. This vector was transformed into E. coli BL21 (DE3) pLysS, and protein expression was achieved in $1 \mathrm{~L}$ of media (ZYM $+0.1 \%$ glucose, $0.1 \%$ glycerol, $2 \mathrm{mM} \mathrm{MgSO}_{4}, 34 \mu \mathrm{g} / \mathrm{mL}$ chloramphenicol, $50 \mu \mathrm{g} / \mathrm{mL}$ carbenicillin) following induction with $0.3 \mathrm{mM}$ IPTG at $37{ }^{\circ} \mathrm{C}$ for $4 \mathrm{~h}$. Cells were harvested, resuspended in $40 \mathrm{~mL}$ of buffer $\mathrm{A}$ (50 mM HEPES, $100 \mathrm{mM} \mathrm{KPO}_{4}$, pH 7.1, 5\% (w/v) glycerol) with added $5 \mathrm{U} / \mathrm{mL}$ DNase, complete protease inhibitor, $5 \mu \mathrm{M} \mathrm{FAD}$, $10 \mathrm{mM} \mathrm{MgCl} 2$, and $0.25 \%$ CHAPS, and sonicated on ice to lyse. Following centrifugation at $20000 \mathrm{~g}$ for $30 \mathrm{~min}$, the soluble fraction was incubated with $2 \mathrm{~mL}$ of settled volume of preequilibrated (buffer A + $0.25 \%$ CHAPS) amylose resin for $30 \mathrm{~min}$ at $4{ }^{\circ} \mathrm{C}$ and then applied to a gravity flow column. The resin was washed with $15 \mathrm{CV}$ buffer A + 0.25\% CHAPS and then $15 \mathrm{CV}$ buffer A without CHAPS. Bound protein was eluted with $10 \mathrm{~mL}$ of buffer A $+20 \mathrm{mM}$ maltose. The same purification procedure was repeated twice on the initial resin flow-throughs; all eluates were combined and concentrated using spin columns. The concentrated prep was then passed through a Superdex 75 10/300 column (running buffer was buffer A), and relevant fractions were collected and concentrated. Aliquots of the resulting weakly yellow solution were flash frozen and stored at $-80{ }^{\circ} \mathrm{C}$ until needed. Protein concentration was measured by spectrophotometric flavin (FAD) analysis, as described in ref 47.

Ndh Activity Assays. MtNdh catalytic activity was measured by monitoring NADH oxidation at $340 \mathrm{~nm}\left(\varepsilon=6220 \mathrm{M}^{-1} \mathrm{~cm}^{-1}\right)$ in a UV-vis spectrophotometer at RT. Reactions $(1 \mathrm{~mL})$ consisted of 0.1 M HEPES, pH 7.0, 10\% DMSO, 0.1-0.5 nM recombinant $\mathrm{MBP}-\mathrm{MtNdh}$, and varying concentrations of Q2 and $\mathrm{NADH}$. Reactions were started by addition of $\mathrm{NADH}$, following $\sim 1$ min preincubation of all other reaction components. Kinetic data was taken at steady state within the first 1 min of the reaction. Background NADH oxidation in the absence of Q2 was measured (typically $<5 \%$ of rate with Q2 present) and subtracted from all subsequent measurements, as required. All kinetic data was plotted and analyzed using GraphPad Prism software. 


\section{ASSOCIATED CONTENT}

\section{S Supporting Information}

The Supporting Information is available free of charge on the ACS Publications website at DOI: 10.1021/acsinfecdis.7b00275.

Compound syntheses and characterization, Met-ID studies of compounds $\mathbf{1}$ and 7 with microsomes with and without GSH, graphs showing metabolic transformations in Met-ID studies, pharmacokinetic studies, anaerobic cidal and intramacrophage activity of compound $\mathbf{1}$, and whole genome sequencing methods and data table (PDF)

\section{AUTHOR INFORMATION}

\section{Corresponding Authors}

*E-mail: hboshoff@niaid.nih.gov.

*E-mail: P.G.Wyatt@dundee.ac.uk.

ORCID $\odot$

Kelly Chibale: 0000-0002-1327-4727

Valerie Mizrahi: 0000-0003-4824-9115

Adrie J. C. Steyn: 0000-0001-9177-8827

Clifton E. Barry III: 0000-0002-2927-270X

Paul G. Wyatt: 0000-0002-0397-245X

Helena I. M. Boshoff: 0000-0002-4333-206X

\section{Present Address}

${ }^{\text {x}}$ P.M.F.: Department of Internal Medicine, University of Pittsburgh, 1218 Scaife Hall, 3550 Terrace Street, Pittsburgh, Pennsylvania 15261, USA.

\section{Author Contributions}

${ }^{\alpha}$ D.M. and P.C.R. contributed equally.

\section{Author Contributions}

H.I.M.B., D.F.W., K.A., and K.Y.R. performed biological experiments on $M T b$. T.R.I. and J.S. performed sequencing analysis of resistant mutants. G.A.P. performed enzyme assays. D.A.L., P.M.F., and A.J.C.S. performed and analyzed bioenergetics. D.M., P.C.R., T.B., J.R.H., K.G., C.S.M., T.-S.F., L.J.S., and K.C. synthesized compounds. P.S., L.E., J.R., Y.S., L.F., M.O.-C., O.E., and K.D.R. performed ADME/PK analysis. H.I.M.B., S.R.G., C.E.B., P.C.R., P.G.W., and V.M. helped with data interpretation. P.C.R., H.I.M.B., and S.R.G. wrote the manuscript. D.F.W., T.-S.F., C.S.M., C.E.B., and D.M. edited the manuscript which was reviewed by all authors.

Notes

The authors declare no competing financial interest.

\section{ACKNOWLEDGMENTS}

This work was funded in part by the Intramural Research Program of NIAID (AI000693-25), by grants from the Foundation for the National Institutes of Health (BARRY11HTB0) with support from the Bill \& Melinda Gates Foundation (OPP1024021), and by the South African Medical Research Council (SAMRC) with funds received from Strategic Health Innovation Partnerships (SHIP) unit of the SAMRC, by the National Research Foundation of South Africa, and OPP1066891 "A Centre of Excellence for Lead Optimization for Diseases of the Developing World”, a joint award from the Wellcome Trust and the Bill \& Melinda Gates Foundation. A.J.C.S. is a Burroughs Welcome Investigator in the Pathogenesis of Infectious Diseases. P.M.F. was a Howard Hughes Medical Institute Medical Research Fellow. We thank David Gray, James Roberts, and Alastair Pate for support with data analysis, compound handling, and data management.

\section{ABBREVATIONS}

$\mathrm{NDH}-2$, type II NADH dehydrogenase; MTb, Mycobacterium tuberculosis; MtNdh, MTb NDH-2; SAR, structure-activity relationship; Kan, kanamycin; INH, isoniazid; RIF, rifampicin; MDR-TB, multidrug resistant TB; XDR-TB, extensively drugresistant tuberculosis; MoA, mechanism of action; MIC, minimum inhibitory concentration; AUC, area under the curve; IMVs, inverted membrane vesicles; OCR, oxygen consumption rate; LLE, ligand-lipophilicity efficiency; ADME, absorption, distribution, metabolism, and excretion; met-ID, metabolite identification; cLogP, calculated $\log \mathrm{P}$; Cli, intrinsic clearance; CFU, colony-forming units; OXPHOS, oxidative phosphorylation; CCCP, carbonyl cyanide $m$-chlorophenyl hydrazine; ETC, electron transport chain; CPZ, chlorpromazine

\section{REFERENCES}

(1) WHO. (2015) Global tuberculosis report 2015, World Health Organization, Geneva, Switzerland; ISBN 978-92-4-156505-9.

(2) WHO. (2010) Treatment of tuberculosis: guidelines, World Health Organization, Geneva, Switzerland; ISBN 978-92-4-154783-3.

(3) Horsburgh, C. R. J., Barry, C. E. I., and Lange, C. (2015) Treatment of Tuberculosis. N. Engl. J. Med. 373 (22), 2149-2160.

(4) Iseman, M. D. (1993) Treatment of Multidrug-Resistant Tuberculosis. N. Engl. J. Med. 329 (11), 784-791.

(5) Migliori, G. B., Loddenkemper, R., Blasi, F., and Raviglione, M. C. (2007) 125 years after Robert Koch's discovery of the tubercle bacillus: the new XDR-TB threat. Is "science" enough to tackle the epidemic? Eur. Respir. J. 29 (3), 423-427.

(6) Velayati, A. A., Masjedi, M. R., Farnia, P., Tabarsi, P., Ghanavi, J., ZiaZarifi, A. H., and Hoffner, S. E. (2009) Emergence of New Forms of Totally Drug-Resistant Tuberculosis Bacilli: Super Extensively DrugResistant Tuberculosis or Totally Drug-Resistant Strains in Iran. Chest 136 (2), 420-425.

(7) Schluger, N. W. (2009) Drug-Resistant Tuberculosis. Chest 136 (2), 333-335.

(8) Palomino, J. C., and Martin, A. (2014) Drug Resistance Mechanisms in Mycobacterium tuberculosis. Antibiotics 3 (3), 317-340.

(9) Zumla, A. I., Gillespie, S. H., Hoelscher, M., Philips, P. P. J., Cole, S. T., Abubakar, I., McHugh, T. D., Schito, M., Maeurer, M., and Nunn, A. J. (2014) New antituberculosis drugs, regimens, and adjunct therapies: needs, advances, and future prospects. Lancet Infect. Dis. 14 (4), 327340.

(10) Selassie, A. W., Pozsik, C., Wilson, D., and Ferguson, P. L. (2005) Why Pulmonary Tuberculosis Recurs: A Population-based Epidemiological Study. Annals of Epidemiology 15 (7), 519-525.

(11) Owens, J. P., Fofana, M. O., and Dowdy, D. W. (2013) Costeffectiveness of novel first-line treatment regimens for tuberculosis. International Journal of Tuberculosis and Lung Disease 17 (5), 590-596.

(12) Lienhardt, C., Vernon, A., and Raviglione, M. C. (2010) New drugs and new regimens for the treatment of tuberculosis: review of the drug development pipeline and implications for national programmes. Curr. Opin. Pulm. Med. 16 (3), 186-193.

(13) Cole, S. T. (2016) Inhibiting Mycobacterium tuberculosis within and without. Philos. Trans. R. Soc., B 371 (1707), 20150506.

(14) Ioerger, T. R., O’Malley, T., Liao, R., Guinn, K. M., Hickey, M. J., Mohaideen, N., Murphy, K. C., Boshoff, H. I. M., Mizrahi, V., Rubin, E. J., Sassetti, C. M., Barry, C. E., Sherman, D. R., Parish, T., and Sacchettini, J. C. (2013) Identification of New Drug Targets and Resistance Mechanisms in Mycobacterium tuberculosis. PLoS One 8 (9), e75245.

(15) Zhang, Y. J., Reddy, M. C., Ioerger, T. R., Rothchild, A. C., Dartois, V., Schuster, B. M., Trauner, A., Wallis, D., Galaviz, S., Huttenhower, C., Sacchettini, J. C., Behar, S. M., and Rubin, E. J. (2013) Tryptophan Biosynthesis Protects Mycobacteria from CD4 T-Cell-Mediated Killing. Cell 155 (6), 1296-1308.

(16) Rao, S. P. S., Alonso, S., Rand, L., Dick, T., and Pethe, K. (2008) The protonmotive force is required for maintaining ATP homeostasis 
and viability of hypoxic, nonreplicating Mycobacterium tuberculosis. Proc. Natl. Acad. Sci. U. S. A. 105 (33), 11945-11950.

(17) DeJesus, M. A., Gerrick, E. R., Xu, W., Park, S. W., Long, J. E., Boutte, C. C., Rubin, E. J., Schnappinger, D., Ehrt, S., Fortune, S. M., Sassetti, C. M., and Ioerger, T. R. (2017) Comprehensive Essentiality Analysis of the Mycobacterium tuberculosis Genome via Saturating Transposon Mutagenesis. mBio 8 (1), e02133-16.

(18) Heikal, A., Hards, K., Cheung, C.-Y., Menorca, A., Timmer, M. S. M., Stocker, B. L., and Cook, G. M. (2016) Activation of type II NADH dehydrogenase by quinolinequinones mediates antitubercular cell death. J. Antimicrob. Chemother. 71 (10), 2840-2847.

(19) Hong, W. D., Gibbons, P. D., Leung, S. C., Amewu, R, Stocks, P. A., Stachulski, A., Horta, P., Cristiano, M. L. S., Shone, A. E., Moss, D., Ardrey, A., Sharma, R., Warman, A. J., Bedingfield, P. T. P., Fisher, N. E., Aljayyoussi, G., Mead, S., Caws, M., Berry, N. G., Ward, S. A., Biagini, G. A., O’Neill, P. M., and Nixon, G. L. (2017) Rational Design, Synthesis, and Biological Evaluation of Heterocyclic Quinolones Targeting the Respiratory Chain of Mycobacterium tuberculosis. J. Med. Chem. 60 (9), 3703-3726.

(20) Yano, T., Kassovska-Bratinova, S., Teh, J. S., Winkler, J., Sullivan, K., Isaacs, A., Schechter, N. M., and Rubin, H. (2011) Reduction of Clofazimine by Mycobacterial Type $2 \mathrm{NADH}$ :Quinone Oxidoreductase: A PATHWAY FOR THE GENERATION OF BACTERICIDAL LEVELS OF REACTIVE OXYGEN SPECIES. J. Biol. Chem. 286 (12), 10276-10287.

(21) Moosa, A., Lamprecht, D. A., Arora, K., Barry, C. E., Boshoff, H. I. M., Ioerger, T. R., Steyn, A. J. C., Mizrahi, V., and Warner, D. F. (2017) Susceptibility of Mycobacterium tuberculosis Cytochrome bd Oxidase Mutants to Compounds Targeting the Terminal Respiratory Oxidase, Cytochrome c. Antimicrob. Agents Chemother. 61 (10), e01338-17.

(22) Alland, D., Steyn, A. J., Weisbrod, T., Aldrich, K., and Jacobs, W. R. (2000) Characterization of the Mycobacterium tuberculosis iniBAC Promoter, a Promoter That Responds to Cell Wall Biosynthesis Inhibition. J. Bacteriol. 182 (7), 1802-1811.

(23) Naran, K., Moosa, A., Barry, C. E., Boshoff, H. I. M., Mizrahi, V., and Warner, D. F. (2016) Bioluminescent Reporters for Rapid Mechanism of Action Assessment in Tuberculosis Drug Discovery. Antimicrob. Agents Chemother. 60 (11), 6748-6757.

(24) Weinstein, E. A., Yano, T., Li, L.-S., Avarbock, D., Avarbock, A., Helm, D., McColm, A. A., Duncan, K., Lonsdale, J. T., and Rubin, H. (2005) Inhibitors of type II NADH:menaquinone oxidoreductase represent a class of antitubercular drugs. Proc. Natl. Acad. Sci. U. S. A. 102 (12), 4548-4553.

(25) Sassetti, C. M., Boyd, D. H., and Rubin, E. J. (2003) Genes required for mycobacterial growth defined by high density mutagenesis. Mol. Microbiol. 48 (1), 77-84.

(26) McAdam, R. A., Quan, S., Smith, D. A., Bardarov, S., Betts, J. C., Cook, F. C., Hooker, E. U., Lewis, A. P., Woollard, P., Everett, M. J., Lukey, P. T., Bancroft, G. J., Jacobs, W. R., and Duncan, K. (2002) Characterization of a Mycobacterium tuberculosis H37Rv transposon library reveals insertions in $351 \mathrm{ORFs}$ and mutants with altered virulenceb. Microbiology 148 (10), 2975-2986.

(27) Griffin, J. E., Gawronski, J. D., DeJesus, M. A., Ioerger, T. R., Akerley, B. J., and Sassetti, C. M. (2011) High-Resolution Phenotypic Profiling Defines Genes Essential for Mycobacterial Growth and Cholesterol Catabolism. PLoS Pathog. 7 (9), e1002251.

(28) Leeson, P. D., and Young, R. J. (2015) Molecular Property Design: Does Everyone Get It? ACS Med. Chem. Lett. 6 (7), 722-725.

(29) Keseru, G. M., and Makara, G. M. (2009) The influence of lead discovery strategies on the properties of drug candidates. Nat. Rev. Drug Discovery 8 (3), 203-212.

(30) Brown, M. F., Avery, M., Brissette, W. H., Chang, J. H., Colizza, K., Conklyn, M., DiRico, A. P., Gladue, R. P., Kath, J. C., Krueger, S. S., Lira, P. D., Lillie, B. M., Lundquist, G. D., Mairs, E. N., McElroy, E. B., McGlynn, M. A., Paradis, T. J., Poss, C. S., Rossulek, M. I., Shepard, R. M., Sims, J., Strelevitz, T. J., Truesdell, S., Tylaska, L. A., Yoon, K., and Zheng, D. (2004) Novel CCR1 antagonists with improved metabolic stability. Bioorg. Med. Chem. Lett. 14 (9), 2175-2179.
(31) Swallow, S. (2015) Fluorine in Medicinal Chemistry. Prog. Med. Chem. 54, 65-133.

(32) Kalgutkar, A. S., and Dalvie, D. (2015) Predicting Toxicities of Reactive Metabolite-Positive Drug Candidates. Annu. Rev. Pharmacol. Toxicol. 55 (1), 35-54.

(33) Stepan, A. F., Walker, D. P., Bauman, J., Price, D. A., Baillie, T. A., Kalgutkar, A. S., and Aleo, M. D. (2011) Structural Alert/Reactive Metabolite Concept as Applied in Medicinal Chemistry to Mitigate the Risk of Idiosyncratic Drug Toxicity: A Perspective Based on the Critical Examination of Trends in the Top 200 Drugs Marketed in the United States. Chem. Res. Toxicol. 24 (9), 1345-1410.

(34) Hartkoorn, R. C., Uplekar, S., and Cole, S. T. (2014) CrossResistance between Clofazimine and Bedaquiline through Upregulation of MmpL5 in Mycobacterium tuberculosis. Antimicrob. Agents Chemother. 58 (5), 2979-2981.

(35) Arora, K., Ochoa-Montaño, B., Tsang, P. S., Blundell, T. L., Dawes, S. S., Mizrahi, V., Bayliss, T., Mackenzie, C. J., Cleghorn, L. A. T., Ray, P. C., Wyatt, P. G., Uh, E., Lee, J., Barry, C. E., and Boshoff, H. I. (2014) Respiratory Flexibility in Response to Inhibition of Cytochrome c Oxidase in Mycobacterium tuberculosis. Antimicrob. Agents Chemother. 58 (11), 6962-6965.

(36) Lamprecht, D. A., Finin, P. M., Rahman, M. A., Cumming, B. M., Russell, S. L., Jonnala, S. R., Adamson, J. H., and Steyn, A. J. C. (2016) Turning the respiratory flexibility of Mycobacterium tuberculosis against itself. Nat. Commun. 7, 12393.

(37) Yano, T., Rahimian, M., Aneja, K. K., Schechter, N. M., Rubin, H., and Scott, C. P. (2014) Mycobacterium tuberculosis Type II NADHMenaquinone Oxidoreductase Catalyzes Electron Transfer through a Two-Site Ping-Pong Mechanism and Has Two Quinone-Binding Sites. Biochemistry 53 (7), 1179-1190.

(38) Shirude, P. S., Paul, B., Roy Choudhury, N., Kedari, C., Bandodkar, B., and Ugarkar, B. G. (2012) Quinolinyl Pyrimidines: Potent Inhibitors of NDH-2 as a Novel Class of Anti-TB Agents. ACS Med. Chem. Lett. 3 (9), 736-740.

(39) Yano, T., Li, L.-S., Weinstein, E., Teh, J.-S., and Rubin, H. (2006) Steady-state Kinetics and Inhibitory Action of Antitubercular Phenothiazines on Mycobacterium tuberculosis Type-II NADHMenaquinone Oxidoreductase (NDH-2). J. Biol. Chem. 281 (17), $11456-11463$.

(40) Heikal, A., Nakatani, Y., Dunn, E., Weimar, M. R., Day, C. L., Baker, E. N., Lott, J. S., Sazanov, L. A., and Cook, G. M. (2014) Structure of the bacterial type II NADH dehydrogenase: a monotopic membrane protein with an essential role in energy generation. Mol. Microbiol. 91 (5), 950-964.

(41) Harbut, M. B., Liu, R., Yang, B., Yano, T., Vilcheze, C., Lockner, J., Guo, H., Franzblau, S. G., Petrassi, M., Jacobs, W. R., Rubin, H., Chatterjee, A. K., and Wang, F. (2018) Small molecules targeting Mycobacterium tuberculosis type II NADH dehydrogenase with antimycobacterial activity. Angew. Chem., Int. Ed. 57, 3478.

(42) Vilchèze, C., Weinrick, B., Leung, L. W., and Jacobs, W. R. (2018) Plasticity of Mycobacterium tuberculosis NADH dehydrogenases and their role in virulence. Proc. Natl. Acad. Sci. U. S. A. 115, 1599.

(43) Camurri, G., and Zaramella, A. (2001) High-throughput liquid chromatography/mass spectrometry method for the determination of the chromatographic hydrophobicity index. Anal. Chem. 73 (15), 37163722.

(44) Valko, K., Nunhuck, S., Bevan, C., Abraham, M. H., and Reynolds, D. P. (2003) Fast Gradient HPLC Method to Determine Compounds Binding to Human Serum Albumin. Relationships with Octanol/Water and Immobilized Artificial Membrane Lipophilicity. J. Pharm. Sci. 92 (11), 2236-2248.

(45) Park, Y., Pacitto, A., Bayliss, T., Cleghorn, L. A. T., Wang, Z., Hartman, T., Arora, K., Ioerger, T. R., Sacchettini, J., Rizzi, M., Donini, S., Blundell, T. L., Ascher, D. B., Rhee, K., Breda, A., Zhou, N., Dartois, V., Jonnala, S. R., Via, L. E., Mizrahi, V., Epemolu, O., Stojanovski, L., Simeons, F., Osuna-Cabello, M., Ellis, L., MacKenzie, C. J., Smith, A. R. C., Davis, S. H., Murugesan, D., Buchanan, K. I., Turner, P. A., Huggett, M., Zuccotto, F., Rebollo-Lopez, M. J., Lafuente-Monasterio, M. J., Sanz, O., Diaz, G. S., Lelièvre, J., Ballell, L., Selenski, C., Axtman, M., Ghidelli- 
Disse, S., Pflaumer, H., Bösche, M., Drewes, G., Freiberg, G. M., Kurnick, M. D., Srikumaran, M., Kempf, D. J., Green, S. R., Ray, P. C., Read, K., Wyatt, P., Barry, C. E., and Boshoff, H. I. (2017) Essential but Not Vulnerable: Indazole Sulfonamides Targeting Inosine Monophosphate Dehydrogenase as Potential Leads against Mycobacterium tuberculosis. ACS Infect. Dis. 3 (1), 18-33.

(46) Boshoff, H. I. M., Reed, M. B., Barry, C. E., and Mizrahi, V. (2003) DnaE2 Polymerase Contributes to In Vivo Survival and the Emergence of Drug Resistance in Mycobacterium tuberculosis. Cell 113 (2), 183193.

(47) Aliverti, A., Curti, B., and Vanoni, M. A. (1999) Identifying and Quantitating FAD and FMN in Simple and in Iron-Sulfur-Containing Flavoproteins. In Flavoprotein Protocols (Chapman, S. K., and Reid, G. A., Eds.), pp 9-23, Humana Press, Totowa, NJ; DOI: 10.1385/1-59259266-x:9. 